\title{
Organisatieveranderingen en competentie- ontwikkeling : Verslag van een enquete bij Het Kantoor : Themarapport werkgelegenheid en scholing 1998
}

Citation for published version (APA):

Borghans, L., van Loo, J. B., de Ruyter, E., de Steur, M. J., Sander, J., \& Vlasblom, J. D. (2000). Organisatieveranderingen en competentie-ontwikkeling : Verslag van een enquete bij Het Kantoor: Themarapport werkgelegenheid en scholing 1998. Researchcentrum voor Onderwijs en Arbeidsmarkt, Faculteit der Economische Wetenschappen. ROA Reports No. 3 https://doi.org/10.26481/umarep.2000003

Document status and date:

Published: 01/01/2000

DOI:

10.26481/umarep.2000003

Document Version:

Publisher's PDF, also known as Version of record

\section{Please check the document version of this publication:}

- A submitted manuscript is the version of the article upon submission and before peer-review. There can be important differences between the submitted version and the official published version of record. People interested in the research are advised to contact the author for the final version of the publication, or visit the DOI to the publisher's website.

- The final author version and the galley proof are versions of the publication after peer review.

- The final published version features the final layout of the paper including the volume, issue and page numbers.

Link to publication

\footnotetext{
General rights rights.

- You may freely distribute the URL identifying the publication in the public portal. please follow below link for the End User Agreement:

www.umlib.nl/taverne-license

Take down policy

If you believe that this document breaches copyright please contact us at:

repository@maastrichtuniversity.nl

providing details and we will investigate your claim.
}

Copyright and moral rights for the publications made accessible in the public portal are retained by the authors and/or other copyright owners and it is a condition of accessing publications that users recognise and abide by the legal requirements associated with these

- Users may download and print one copy of any publication from the public portal for the purpose of private study or research.

- You may not further distribute the material or use it for any profit-making activity or commercial gain

If the publication is distributed under the terms of Article 25fa of the Dutch Copyright Act, indicated by the "Taverne" license above, 


\title{
Organisatieveranderingen en competentie-ontwikkeling
}

\author{
Verslag van een enquête bij Het Kantoor \\ Themarapport \\ Werkgelegenheid en scholing 1998
}

ROA-R-2000/3

\author{
Lex Borghans \\ Jasper van Loo \\ Esther de Ruyter \\ Margot de Steur \\ Jos Sanders \\ Jan Dirk Vlasblom
}

Researchcentrum voor Onderwijs en Arbeidsmarkt

Faculteit der Economische Wetenschappen en Bedrijfskunde Universiteit Maastricht

Maastricht, maart 2000 
ISBN 90-5321-270-1

SEC99.171/LB 


\section{Inhoud}

Bladzijde

Voorwoord

Samenvatting iii

1 Inleiding 1

1.1 Inleiding 1

1.2 Opzet van het rapport 5

2 Het Kantoor $\quad 7$

2.1 Inleiding $\quad 7$

2.2 Dossiermedewerkers 9

3 Competenties gemeten: Belang en aanwezigheid 11

3.1 Inleiding 11

$\begin{array}{ll}3.2 \text { Het oordeel van de medewerkers } & 11\end{array}$

$\begin{array}{ll}3.3 \text { Het oordeel van de managers } & 12\end{array}$

$\begin{array}{lr}3.4 \text { Beoordeling managers versus medewerkers } & 17\end{array}$

4 De allocatie van arbeid $\quad 19$

4.1 Inleiding $\quad 19$

4.2 Werktijd en overwerk 19

$\begin{array}{ll}4.3 \text { Werkzaamheden en taakverdeling } & 21\end{array}$

5 Kwalificatieproblemen en hun oorzaken $\quad 27$

5.1 Inleiding $\quad 27$

$\begin{array}{ll}5.2 \text { Inwerktijd } & 27\end{array}$

5.3 Veranderingen in het werk 28

6 Consequenties voor de arbeidsmarktpositie 33

6.1 Inleiding 33

6.2 Kans op nieuw werk en risico op werkloosheid 33

7 Wat kan er worden gedaan? $\quad 41$

7.1 Inleiding 41

7.2 Wat doen medewerkers bij concrete problemen in het werk?

7.3 Cursussen en leerbronnen van competenties 44

$\begin{array}{ll}\text { 7.4 Aspiraties en zelfontwikkeling } & 52\end{array}$

8 Een balans $\quad 55$ 


\section{Voorwoord}

In het kader van het Europese scholingsprogramma ESF 4 voert het Researchcentrum voor Onderwijs en Arbeidsmarkt onderzoek uit dat tot doel heeft in kaart te brengen voor welke groepen additionele scholing van belang kan zijn ter bescherming van hun positie op de arbeidsmarkt. In het kader van dit Werkgelegenheid- en Scholing-Observatorium (WSO) wordt periodiek het overzichtsrapport Werkgelegenheid en Scholing ${ }^{1}$ uitgebracht. Daarnaast wordt er binnen het WSO onderzoek uitgevoerd dat tot doel heeft de bestaande inzichten over kennisveroudering, compenties en scholing te verdiepen. Het is de bedoeling dat dit verdiepende onderzoek de betekenis van het overzichtsrapport Werkgelegenheid en Scholing zal vergroten.

In 1998 is vanuit dit perspectief een onderzoek gestart naar de betekenis van veranderingen in een organisatie voor de competenties en daarmee het functioneren van de medewerkers. ABP/USZO, een groot bedrijf in de financiële sector, was bereid medewerking te verlenen aan dit onderzoek waarbij een honderdtal medewerkers en hun managers mondeling zijn geënquêteerd. Daarnaast zijn enkele gesprekken met directeuren en HRM-medewerkers gevoerd. In dit rapport wordt verslag gedaan van dit onderzoek. Omdat het ons in dit rapport gaat om veranderingsprocessen die zich op de gehele arbeidsmarkt af kunnen spelen en niet om een beschrijving van dit specifieke bedrijf, wordt het bedrijf in het rapport als 'Het Kantoor' aangeduid.

De projectleiding van het onderzoek was in handen van Lex Borghans. Daarnaast speelde Jasper van Loo een centrale rol bij de ontwikkeling van de vragenlijst, de coördinatie van de projectuitvoering en het schrijven van het rapport. Margot de Steur en Esther de Ruyter hebben bijgedragen aan de ontwikkeling van de vragenlijst. Jos Sanders heeft het programmeerwerk voor de enquête voor zijn rekening genomen. Samen met Esther de Ruyter heeft hij de enquêtes onder de medewerkers en hun managers afgenomen. Jan Dirk Vlasblom, ten slotte, heeft een aanzienlijk deel van het programmeerwerk ten behoeve van de data-analyse verricht.

Onze dank gaat uiteraard uit naar ABP/USZO, het bedrijf dat bereid was medewerking te verlenen aan dit project. Met name de inzet en betrokkenheid van Mirjam Biemans was hierbij van zeer grote waarde. Verder willen wij Jan van der Velden en Fred Straatjes van het Ministerie van Sociale Zaken en Werkgelegenheid bedanken voor hun commentaar.

1 ROA, Werkgelegenheid en Scholing 1997, ROA-R-1998/1, Maastricht. 


\section{Samenvatting}

Door het toenemende belang van computers en informatie- en communicatietechnologie, snelle en ingrijpende veranderingen in de organisatiestructuur van bedrijven en een toegenomen concurrentie - zowel nationaal als internationaal tussen bedrijven, is de laatste jaren het belang van kennis en competenties binnen een organisatie nadrukkelijk naar voren gekomen. Termen als employability, een leven lang leren en competentiemanagement weerspiegelen het toenemende belang van kennis voor organisaties. Hierbij speelt niet alleen dat kennis als zodanig steeds belangrijker wordt, maar ook dat werknemers zich steeds sneller aan moeten passen aan veranderende omstandigheden en dus kennis ook steeds sneller veroudert.

De genoemde ontwikkelingen kunnen overigens niet los van elkaar worden gezien. De introductie van de computer vereist direct bepaalde computervaardigheden van medewerkers die vroeger niet van belang waren. Economen hebben er echter op gewezen dat het waarschijnlijk veel belangrijker is dat, doordat de computer is doorgedrongen in alle aspecten van het werkproces, een andere organisatie van de werkzaamheden mogelijk is geworden. Doordat de computer bepaalde activiteiten die vroeger door medewerkers zelf moesten worden verricht over heeft genomen, is ook in de concurrentie met andere bedrijven de nadruk veel sterker komen te liggen op juist die elementen van het werk waar de computer niet voor ingezet kan worden. Hierdoor zijn zaken zoals communicatie met de klant, maatwerk, team work en aanpassingsvermogen in belang toegenomen.

Het onderzoek waarvan in dit rapport verslag wordt gedaan heeft tot doel in kaart te brengen welke betekenis organisatieveranderingen hebben gehad voor mogelijke kennisveroudering van de medewerkers, de mogelijke gevolgen hiervan en de wijze waarop nieuwe competenties worden verworven. Het onderzoek bestond uit een mondelinge enquête van 100 dossiermedewerkers bij 'Het Kantoor', 50 bij de businessunit 'Leven' en 50 bij de businessunit van 'Risico', een gesprek met hun managers en enkele gesprekken met directeuren en HRM-functionarissen over deze problematiek. De hoofdvragen zijn:

- Wat zijn de oorzaken van kennisveroudering?

- Wat zijn de mogelijke consequenties van kennisveroudering en kennisachterstand?

- Wie treft dit met name?

- Wat kan er tegen worden gedaan?

Uit het onderzoek komt naar voren dat veranderende regelgeving, de introductie van de computer en expliciete of impliciete organisatorische veranderingen ook bij Het Kantoor door de medewerkers als de belangrijkste veranderingen van de afgelopen jaren worden gezien. Op zich blijkt dat een grote groep medewerkers zich adequaat aan heeft weten te passen aan deze ingrijpende veranderingen. Met elk van de drie 
genoemde veranderingen heeft slechts een kleine minderheid van de dossiermedewerkers daadwerkelijk problemen gehad. Omgekeerd heeft het bedrijf onder andere door dit veranderingsproces royaal te ondersteunen met cursussen een aanzienlijke bijdrage aan de omschakeling geleverd.

Veel medewerkers zijn overigens wel van mening dat het aanpassingsproces beter had kunnen verlopen als men meer steun had gekregen. Opmerkelijk is hierbij dat als aan de dossiermedewerkers wordt gevraagd op welke wijze zij bepaalde competenties hebben verworven, cursussen slechts een beperkte rol spelen. Werkervaring en contacten met collega's blijken veel belangrijker te zijn dan wellicht zou worden verwacht. Dit betekent dan wel dat cursussen minder belangrijk zijn in het leerproces dan vaak wordt verondersteld, dan wel dat de aard van de cursussen niet goed aansluit bij de problemen die de medewerkers ondervinden. Het is kennelijk moeilijk om centraal vanuit de organisatie vast te stellen op welke wijze de competentieontwikkeling van de medewerkers het beste ondersteund kan worden.

Gezien de aard van de maatschappelijke ontwikkelingen concluderen wij dan ook uit de resultaten van het onderzoek bij Het Kantoor dat het steeds belangrijker wordt dat medewerkers zelf kunnen aangeven op welke wijze zij zich verder denken te kunnen ontplooien. Dit betekent dat er aan de ene kant een grotere verantwoordelijkheid bij de medewerker komt te liggen om zelf initiatieven voor zijn ontwikkeling te nemen. Aan de andere kant betekent dit voor de organisatie dat zij de competentie-ontwikkeling van de medewerkers wellicht op een andere wijze zal moeten gaan ondersteunen.

Een drietal hoofdfactoren staan een dergelijke aanpassing van verantwoordelijkheden wellicht nog in de weg. In de eerste plaats blijkt dat zowel aan de kant van de medewerker als aan de kant van de managers nog geen helder beeld bestaat van de sterke en zwakke punten van de betreffende dossiermedewerker. Een adequaat beeld van de competenties waarover men beschikt, is uiteraard een voorwaarde voor verdere competentie-ontwikkeling op maat. Ten tweede lijken dossiermedewerkers nog slechts in beperkte mate de verantwoordelijkheid voor de eigen ontwikkeling te voelen. Een grote groep medewerkers gaat er van uit dat men niet snel voor zijn baan bij Het Kantoor hoeft te vrezen, de bereidheid om zelf in opleidingen te investeren is niet erg hoog en het informele leerproces waarbij dossiermedewerkers in onderling overleg problemen oplossen is nog niet voor iedereen gemeengoed. Omgekeerd lijkt het er op dat ook de organisatie een dergelijke attitude die gericht is op de eigen ontwikkeling beter zou kunnen ondersteunen. Hierbij kan gedacht worden aan cursussen die beter aansluiten bij de problemen die de medewerkers in de organisatie ondervinden. Daarnaast kan wellicht bij de verdeling van de werkzaamheden en de wijze waarop medewerkers elkaar in hun bezigheden ondersteunen meer nadruk op een 'leerrijke' werkomgeving worden gelegd. Overigens laat het onderzoek zien dat zowel de medewerkers zelf, als hun manager een onvolledig beeld van de competenties van de dossiermedewerkers hebben. Duidelijkheid over iemands sterke en zwakke punten, bij zowel de medewerker als de manager, lijkt een basisvoorwaarde voor gerichte 
competentie-ontwikkeling te zijn. Opmerkelijk is in dit verband verder dat de relatie tussen de waardering door de manager en de beloning van de servicemedewerker, zowel qua inkomen als qua baanzekerheid niet sterk ontwikkeld lijkt te zijn. Alleen de bonussen vormen wel een duidelijke schakel tussen de verwachtingen die de organisatie van de medewerkers heeft en de waardering die zij van de organisatie krijgen.

Een aantal specifieke punten uit het rapport kunnen deze grote lijn wellicht illustreren:

In hoofdstuk 2 komt naar voren dat de medewerkers qua achtergrond niet gelijkmatig over de afdelingen zijn verdeeld. In ieder geval naar leeftijd blijken er afdelingen te zijn met veel jonge medewerkers, terwijl bij andere afdelingen veel ouderen werken. De gemiddelde leeftijd varieert tussen 36 en 50 jaar. Dit zou tot gevolg kunnen hebben dat voor zover competenties samenhangen met leeftijd, de mogelijkheid tot taakverdeling binnen een afdeling beperkt is. Ook de ervaringsoverdracht van ouderen op jongeren wordt hierdoor mogelijk beperkt.

in hoofdstuk 3 komt naar voren dat de kwaliteiten van medewerkers op het gebied van planning, rekenen en vakkennis het meeste bijdragen aan het beeld dat een manager heeft over het functioneren van de medewerker. Bij Leven blijkt echter vakkennis en adviseren van klanten veel belangrijker te zijn dan bij Risico, terwijl bij Risico met name de genoemde planning de belangrijkste factor in de beoordeling blijkt te zijn.

Deze waardering door de manager blijkt overigens niet parallel te lopen aan de beloning van de medewerkers. Ook als gecorrigeerd wordt voor leeftijd en ervaring blijkt bij Risico alleen de waardering voor rekenen met de beloning samen te hangen. Bij Leven hebben instrueren, vakkennis en schrijven een positieve invloed en heeft klanten adviseren en computerkennis een negatieve invloed op de beloning. Zoals is opgemerkt, blijkt uit een eerste analyse dat de bonussen die het bedrijf zijn medewerkers toekent, wel een duidelijke samenhang laten zien tussen beoordeling en waardering.

Er blijken, zoals ook hierboven reeds is opgemerkt, ook zeer grote verschillen te bestaan tussen de waardering die de medewerker en zijn manager geven voor diverse aspecten van zijn functioneren. Voor de manager blijkt het moeilijk te zijn een adequaat onderscheid te maken tussen iemands kwaliteiten op het gebied van vakkennis, computervaardigheden en rekenen. Medewerkers die een lagere algemene beoordeling van hun manager krijgen, geven zelf met name aan goed te zijn in minder grijpbare zaken als teamwork en klanten adviseren. Om adequaat te kunnen werken aan de verdere competentie-ontwikkeling van het personeel lijkt het daarom van belang dat zowel de leidinggevende als de medewerker zelf een beter beeld van zijn functioneren krijgt. 
De competenties waarover medewerkers beschikken blijken van invloed te zijn op het werk dat ze verrichten. Dit geldt in de eerste plaats voor de aard van de werkzaamheden. Daarnaast blijken medewerkers met een hoge algemene waardering doorgaans minder over te werken. Kennelijk hebben zij hun werk meer onder controle, waardoor het voor hen beter mogelijk is het werk binnen de gestelde tijd af te ronden. Alleen medewerkers die een goede beoordeling krijgen voor hun vakkennis, blijken juist langer door te werken. De verklaring hiervoor zou kunnen zijn dat de organisatie hen juist meer werk toeschuift.

Bij Leven wordt $42 \%$ van de werktijd in beslag genomen door berekeningen, terwijl dit bij Risico slechts $25 \%$ is. Beheerswerkzaamheden kosten bij Leven $42 \%$ van de tijd en bij Risico $62 \%$. Sturing blijkt bij Leven $16 \%$ van de tijd in beslag te nemen, terwijl dit bij Risico $13 \%$ is.

Het overgrote deel van de medewerkers is van oordeel dat de afgelopen tijd belangrijke veranderingen hebben plaatsgevonden bij Het Kantoor. Met name veranderingen in regelgeving, automatisering en organisatorische veranderingen worden veel genoemd. Organisatorische veranderingen brengen hiervan de meeste problemen met zich mee. Degenen die moeite hadden met veranderingen in de regelgeving blijken vaak de medewerkers te zijn met een lagere opleiding en lagere waarderingen van hun managers. Deze groep geeft dan ook aan grote problemen te verwachten als men op zoek zou moeten gaan naar een baan buiten Het Kantoor. De organisatorische veranderingen blijken echter met name een probleem te vormen voor de jonge hoger opgeleide medewerkers. Hoewel deze groep de kans om de baan kwijt te raken relatief hoog inschat, verwachten deze medewerkers juist weinig problemen bij het zoeken van ander werk.

Van de totale groep dossiermedewerkers verwacht slechts $15 \%$ vrijwel geen of geen moeite te hebben met het vinden van ander werk buiten Het Kantoor. Zestig procent denkt juist (zeer) veel moeite hiermee te hebben. Daar staat tegenover dat slechts $17 \%$ van de medewerkers bang is de baan bij Het Kantoor kwijt te raken. Zowel voor degenen die deze kans hoog inschatten als voor degenen die deze kans laag inschatten is (gebrek aan) vertrouwen in de organisatie de meest genoemde reden. Omdat medewerkers aan de ene kant denken dat ze moeite zullen hebben met het vinden van ander werk, maar aan de andere kant er van uit gaan dat ze hun werk zullen behouden, zou men zich, ook gelet op het ontbreken van een duidelijke relatie tussen competenties en beloning, af kunnen vragen of de medewerkers voldoende de noodzaak van competentie-ontwikkeling inzien.

Opmerkelijk is verder dat de tijd die medewerkers nodig denken te hebben om ingewerkt te raken sterk uiteen kan lopen. Dit roept de vraag op in hoeverre de leerbehoefte van medewerkers onderling verschilt. Met name vrouwen denken over het algemeen veel minder tijd nodig te hebben om zich in te werken dan mannen.

Ten slotte valt het op dat medewerkers relatief weinig aangeven dat ze dingen die voor het werk van belang zijn hebben geleerd bij een cursus. Als hen echter 
gevraagd wordt hoe ze denken meer te kunnen leren blijken ze echter toch vaak een cursus aan te geven. Deze discrepantie kan twee dingen betekenen. Ten eerste zou het zo kunnen zijn dat er voor de medewerkers geen geschikte cursussen beschikbaar zijn. Ten tweede is het echter ook zeer goed mogelijk dat medewerkers ten onrechte toch nog hoge verwachtingen van cursussen hebben, terwijl deze in de praktijk minder op leveren dan wellicht wordt verwacht. Deze mogelijk verklaringen samen nemend, lijkt de conclusie te mogen worden getrokken dat gerichte werkervaring of cursussen die meer geënt zijn op de werkpraktijk wellicht meer te bieden hebben dan traditionele cursussen.

Aan de hand van een analyse van de veranderingsprocessen bij een specifiek bedrijf heeft dit rapport laten zien dat maatschappelijke en organisatorische veranderingen op velerlei wijze tot problemen in het functioneren van medewerkers kunnen leiden. Hoewel scholing een bijdrage kan leveren aan het verkleinen van deze problemen is het niet zo dat cursussen altijd een adequate oplossing vormen. De wijze waarop het werk wordt ingericht, de keuze van eventuele cursussen en de houding van zowel medewerkers als bedrijf bepalen in hoge mate het succes van beleid gericht op competentie-ontwikkeling. Om ook op landelijk niveau een goed beeld te krijgen van de wijze waarop mensen middels onderwijs, scholing en werkervaring hun competenties weten aan te passen aan de veranderende behoeftes van de arbeidsmarkt, lijkt het van belang in de gegevensverzameling hieraan meer aandacht te geven. Enquêtes waarin expliciet aandacht wordt geschonken aan de kennis en vaardigheden waarover mensen beschikken en de eisen die het werk stelt lijken daarmee van groot belang ter ondersteuning van onderzoek en beleid op dit front. 


\section{Inleiding}

\subsection{Inleiding}

Om adequaat te kunnen functioneren op de arbeidsmarkt spelen de kennis en vaardigheden waarover mensen beschikken een belangrijke rol. Werk waarin het alleen draait om het beschikbaar stellen van de tijd en het verrichten van fysieke inspanningen, komt in Nederland al sinds lange tijd nauwelijks meer voor. De laatste tijd is echter de maatschappelijke interesse voor kennis als economische factor sterk toegenomen. Op het niveau van bedrijven blijkt dit uit de toegenomen belangstelling voor zaken zoals Human Resource Management (HRM) en kennismanagement. HRM richt zich vooral op de ontwikkeling van de individuele medewerkers. Bij kennismanagement gaat het er om om de kennis die er in een bedrijf aanwezig is op een optimale manier beschikbaar te stellen. Bij een aantal grotere bedrijven wordt expliciet beleid gevoerd om het opleidingsniveau van het personeel te verhogen, terwijl ook arbeidsmarktbreed de eisen die aan personeel in een bepaald beroep worden gesteld doorgaans blijken toe te nemen.

Ook in het beleid kan een toenemende belangstelling voor de rol van kennis in de economie worden waargenomen. Zowel nationaal als internationaal (bij bijvoorbeeld de Europese Commissie en de OECD) worden initiatieven genomen om training van werkenden en werklozen te stimuleren en staat met name het idee van een leven lang leren in de aandacht.

Vaak worden het toegenomen belang van computers en informatie- en communicatietechnologie, veranderingen in de organisatiestructuur en een toegenomen nationale en internationale concurrentie als oorzaken voor deze ontwikkelingen gezien.

Deze ontwikkelingen hangen overigens waarschijnlijk nauw met elkaar samen. Doordat de computer veel werkplekken is binnengedrongen, is er allereerst natuurlijk een behoefte aan computervaardigheden ontstaan. Belangrijker lijkt echter te zijn dat door de automatisering een aantal werkzaamheden veel minder tijd en kennis is gaan vergen. Het accent van het werk dat de medewerkers verrichten is daardoor verschoven naar juist die taken waar computers niet ingezet kunnen worden. Organisaties hebben zich impliciet of expliciet aangepast aan deze nieuwe omstandigheden en de concurrentie tussen bedrijven wordt juist op deze elementen gevoerd.

In dit rapport zal gekeken worden naar de competenties van medewerkers bij Het Kantoor. Het Kantoor is de fictieve naam voor een groot bedrijf in de financiële sector. Ook bij Het Kantoor doen de genoemde ontwikkelingen zich voor. Hierdoor is het Kantoor steeds hogere eisen aan haar werknemers gaan stellen: "De huidige verkorte $\mathrm{HBO}$-opleiding is een goed voorbeeld van een opleiding die gericht is op upgrading", vertelt een HRM-functionaris. 
"De verkorte HBO-opleiding is bedoeld om dossiermedewerkers met enige potentie de mogelijkheden te bieden zich op te werken van dossiermedewerker naar een nog in te vullen zwaardere functie. Om een verdere invulling te geven aan de upgrading van het personeel, wordt ook bij de selectie van nieuwe medewerkers met name gezocht naar hoger opgeleide jongeren."

Hij spreekt bij het zittende personeel dan ook van

"Een oudere populatie, die gemiddeld op een MBO-niveau zit en dat lijkt een ongunstige situatie voor de toekomst. De upgrading van het personeel is noodzakelijk, omdat het werk dusdanig verandert, dat de administratief technische kwaliteiten van medewerkers minder van belang worden en de adviesvaardigheden en de relationele kwaliteiten meer nadruk krijgen. Dit als gevolg van de grotere behoefte aan informatie die ontstaat bij de klanten."

De aanleiding voor de toegenomen belangstelling voor kennis betekent uiteraard niet dat tot voor kort de kennis en vaardigheden van werkenden er niet toe deden. De problematiek is echter in het daglicht komen te staan doordat het afgelopen decennium bij een groot aantal bedrijven veranderingen hebben plaatsgevonden die tot gevolg hadden dat de kennis waarover mensen beschikten in een snel tempo verouderd raakte. Mensen die al lange tijd goed ingewerkt waren en hun vak beheersten dreigden daardoor deze comfortabele positie in een snel tempo te verliezen. Met name de genoemde introductie van computers in het gehele bedrijfsproces en organisatorische veranderingen betekenden voor een groot aantal bedrijven dat er ingrijpende aanpassingen waren vereist. Daarnaast kregen veel bedrijven, door een toenemende nationale en internationale concurrentie, noodgedwongen te maken met veranderingen in het productieproces.

Deze kennisveroudering heeft ingrijpende consequenties voor de betreffende bedrijven, maar uiteraard ook voor hun personeel. Bedrijven staan voor de beslissing hoe ze zich aan zullen passen aan deze veranderingsprocessen. Binnen de kaders van wat sociaal aanvaardbaar is, maar ook onder een sterke concurrentiedruk, dienen ze erover te beslissen in welke mate er nieuw en beter opgeleid personeel zal worden geworven en in hoeverre verdere ontwikkeling en opleiding van het bestaande personeel plaats zal moeten vinden. Ook de manier waarop een dergelijk ingrijpend veranderingsproces moet worden opgezet is verre van triviaal. Voor de werknemers betekenen deze veranderingen dat een jarenlange positie binnen het bedrijf ineens niet meer zo vanzelfsprekend is. Zij zullen daardoor moeten accepteren dat hun rol binnen het bedrijf sterk verandert of moeten zorgen dat ze meegaan in het veranderingsproces en wellicht via cursussen, maar ook door een meer leergerichte instelling op het werk hun competenties aan moeten passen aan de nieuwe eisen die het werk stelt.

Vaak wordt aangenomen dat de genoemde ingrijpende veranderingen op het werk zeker geen eenmalige schokken zijn geweest. Verondersteld wordt dat bedrijven door technologische vernieuwingen en de toenemende concurrentie voortdurend 
gedwongen zullen worden ingrijpende aanpassingsprocessen door te voeren. Kennis zal in deze gedachtengang daardoor blijven verouderen en men zal zich dus in moeten stellen op de voortdurende noodzaak van aanpassingsprocessen. Hoewel nog niet duidelijk is of dergelijke veranderingsprocessen de komende tijd door zullen blijven gaan, zou dit betekenen dat zowel bedrijven als werknemers alerter zullen moeten worden op hun positie. Zowel van het bedrijf als van het individu vergt dit dat men zich bewuster wordt van de eigen positie, sneller signaleert dat veranderingen nodig zijn en vervolgens ook het vermogen en de bereidheid heeft zich daadwerkelijk aan de nieuwe omstandigheden aan te passen.

Om een dergelijke bewustere houding van zowel bedrijven als van het personeel mogelijk te maken lijkt het essentieel om meer inzicht te krijgen in de manier waarop medewerkers omgaan met dergelijke veranderingsprocessen. Het Kantoor is een bedrijf dat de laatste jaren in sterke mate geconfronteerd is met de al eerder genoemde veranderingen en ook de komende jaren nog ingrijpende veranderingen voor de kiezen zal krijgen. De analyse van de manier waarop de medewerkers van Het Kantoor om zijn gegaan met deze veranderingen kan dan ook een belangrijke bijdrage leveren aan de inzichten op dit terrein. Dit onderzoek richt zich daarom op de vraag welke gevaren er op de loer liggen, als de vereiste kennis en vaardigheden in een snel tempo veranderen en op welke manier dit het functioneren van mensen in deze organisaties kan bedreigen.

In dit rapport gaan we met name in op een viertal vragen:

- Wat zijn de oorzaken van kennisveroudering?

- Wat zijn de mogelijke consequenties van kennisveroudering en kennisachterstand?

- Wie treft dit met name?

- Wat kan er tegen worden gedaan?

Deze centrale vragen zijn direct gerelateerd aan de kernveronderstellingen zoals die in het theoretisch kader van het Werkgelegenheid- en Scholing-Observatorium (WSO) gebruikt worden. WSO is er op gericht om in kaart te brengen op welke plaatsen en bij welke groepen op de arbeidsmarkt kennisachterstanden dreigen te ontstaan, die de positie van de betrokken werknemers in gevaar kunnen brengen. Deze kennisachterstanden kunnen wellicht via scholing worden verholpen. Het WSO-raamwerk is gebaseerd op een aantal vereenvoudigende veronderstellingen die in het algemeen moeilijk geverifieerd kunnen worden. Allereerst is de gedachte dat technologische en organisatorische veranderingen leiden tot kennisachterstand. Vervolgens wordt er van uit gegaan dat juist de mensen die dergelijke kennisachterstand oplopen de grootste risico's lopen voor verlies van hun werk. Risicofactoren zoals tijdelijke aanstellingen of werken in een sector met veel fluctuaties in de werkgelegenheid vergroten dit risico op verlies van werk. Ten slotte wordt aangenomen dat scholingsinspanningen en de bereidheid en het vermogen van medewerkers om zich aan te passen aan nieuwe omstandigheden (employability) een remedie zijn waarmee kwalificatieveroudering kan worden tegengaan. 
Om meer inzicht te krijgen in de processen die ten grondslag liggen aan kwalificatieveroudering en te kunnen onderzoeken hoe kwalificatietekorten kunnen worden tegengegaan worden de relaties, zoals die in het theoretisch kader van het WSO worden verondersteld, in dit rapport op een micro-niveau geanalyseerd. Het rapport is gebaseerd op een mondelinge enquête onder medewerkers en hun managers die bij Het Kantoor heeft plaatsgevonden. Door in te gaan op de veranderingen die bij Het Kantoor hebben plaatsgevonden en de wijze waarop de medewerkers daarmee zijn omgegaan, wordt een analyse gemaakt van de bestaande theoretische denkkaders om zo een scherper beeld te krijgen van de betekenis van veranderingen in een organisatie voor de competenties van medewerkers. Aan de hand van de gegevens over de medewerkers van Het Kantoor worden deze punten geïllustreerd en wordt getoond hoe de competentie-ontwikkeling van medewerkers in relatie tot de veranderingen in het bedrijf in kaart kunnen worden gebracht. Hiermee zal de balans met betrekking tot de competentie-ontwikkeling bij Het Kantoor worden opgemaakt.

De aanpak in dit onderzoek is geweest om een relatief kleine groep medewerkers te onderzoeken, maar deze groep wel het hemd van het lijf te vragen, zodat alle facetten die een rol spelen bij de competentie-ontwikkeling direct en open werden gevraagd. Hierdoor is het mogelijk de bestaande denkkaders over de betekenis van veranderingen die een organisatie ondergaat expliciet te toetsen zonder dat daarbij vooraf specifieke veronderstellingen moeten worden gemaakt. Doordat zowel de medewerkers als hun managers uitgebreid zijn ondervraagd, is het mogelijk om zowel individuele invloeden op de competentie-ontwikkeling als de invloed van de directe leiding op dit proces in beeld te brengen. Het Kantoor kent twee bedrijfsonderdelen die elk hun eigen voorgeschiedenis hebben. In het rapport zal daarom ook op de verschillen tussen deze bedrijfsonderdelen worden ingegaan. De enquête is zoals gezegd onder een relatief kleine groep medewerkers gehouden. Doordat er voor gekozen is om een qua functie zeer homogene groep uit te kiezen is het ondanks deze beperkte omvang van de steekproef toch mogelijk statistisch verantwoorde analyses uit te voeren. De variatie in de achtergrondkenmerken is immers beperkt. In dit rapport worden de belangrijkste bevindingen gepresenteerd. Dat betekent dat met name tabellen zijn opgenomen die interessante verschillen tussen groepen of situaties naar voren brengen. Om de leesbaarheid te vergroten wordt hierbij niet ingegaan op de formele statistische vergelijking van de uitkomsten. De verschillen die in de tekst worden genoemd zijn echter altijd statistisch significant. Dit wil echter nog niet zeggen dat er ook een causaal verband bestaat. Als er onder de jongeren meer vrouwen zijn dan onder de ouderen en jongeren bepaalde competenties hebben die bij ouderen minder aanwezig zijn, dan zal zowel naar leeftijd als naar geslacht een verband gevonden worden met deze competenties. Om die reden is in principe steeds ook een regressievergelijking geschat die een beeld kan geven van deze verbanden. Voor de leesbaarheid zijn deze resultaten niet opgenomen, maar worden belangrijke bevindingen in de tekst genoemd. 


\subsection{Opzet van het rapport}

De verdere indeling van dit rapport is als volgt. In hoofdstuk 2 wordt een algemene beschrijving gegeven van het bedrijf waarin het competentieonderzoek is verricht. In hoofdstuk 3 staat de meting van de competenties van de medewerkers centraal. Niet alleen de kwaliteit van de competenties, die door de medewerkers zelf en door hun managers wordt beoordeeld, maar ook het belang ervan in het productieproces van Het Kantoor zal in dit hoofdstuk uitgebreid aan de orde komen.

Kwalificatieproblemen kunnen op verschillende manieren opgelost worden. Naast scholing van de medewerkers is het bijvoorbeeld ook mogelijk de taken in een bedrijf zo in te delen dat er rekening gehouden wordt met de individuele capaciteiten van de medewerkers. Deze allocatie van de werkzaamheden staat centraal in het vierde hoofdstuk.

In hoofdstuk 5 komen kwalificatieproblemen en hun oorzaken uitgebreid aan de orde. In dit hoofdstuk wordt onder meer ingegaan op de wijze waarop medewerkers zich aanpassen aan de veranderende behoeftes van de organisatie en wat de belangrijkste problemen bij veranderingen zijn.

Wanneer er als gevolg van veranderingen in het werk kwalificatieveroudering optreedt, hoeft dat nog niet direct te betekenen dat de positie van medewerkers binnen Het Kantoor in gevaar komt. Opgetreden kwalificatieveroudering kan echter de (toekomstige) positie op de externe arbeidsmarkt beïnvloeden. In hoofdstuk 6 wordt deze positie nader geanalyseerd waardoor het mogelijk wordt om risicogroepen binnen Het Kantoor te identificeren.

De oplossingen voor kwalificatieproblemen kunnen, zoals gezegd, op een aantal vlakken liggen. Met behulp van de grote hoeveelheid gedetailleerde informatie die dit onderzoek heeft opgeleverd kunnen we naast de oplossingen die door het WSO-raamwerk worden aangereikt (scholingsinspanningen en employability) ook ingaan op remedies met een ander karakter, zoals bijvoorbeeld het raadplegen van collega's of baas bij een concreet probleem in het werk. In hoofdstuk 7 wordt ingegaan op de verschillende instrumenten die gebruikt kunnen worden bij het bestrijden van kwalificatieveroudering en wordt de manier waarop medewerkers die instrumenten ervaren geanalyseerd.

In hoofdstuk 8, ten slotte, wordt de balans opgemaakt door de inzichten die dit rapport oplevert nog eens kort samen te vatten. 


\section{Het Kantoor}

\subsection{Inleiding}

Het Kantoor is een onderneming in de financiële sector. Het Kantoor bestaat uit twee bedrijfsonderdelen, Risico en Leven. De bedrijfsonderdelen zijn verdeeld in een aantal afdelingen, die elk een specifieke taak hebben. Bij Risico werken in de meeste afdelingen rond de 25 mensen onder leiding van een manager. Bij Leven bestaan de meeste afdelingen uit 15 à 20 medewerkers en een manager.

De bedrijfsonderdelen Risico en Leven verschillen in de producten/diensten die ze aanbieden, maar de werkzaamheden van de grootste groep werknemers - de zogenaamde dossiermedewerkers - zijn in beide bedrijfsonderdelen toch gelijksoortig. De dossiermedewerkers hebben als belangrijkste taak om aanvragen voor uitkeringen te behandelen en de gegevens van klanten te beheren en indien nodig, te wijzigen. Dit werk wordt uitgevoerd in grote kantoortuinen waar de dossiermedewerkers achter computers met grote beeldschermen de dossiers van de klanten door kunnen nemen en zo de aanvragen grotendeels achter hun PC kunnen behandelen.

Het Kantoor staat midden in de overgang van een bedrijf met een vaste, door regelgeving vastgelegde groep klanten, naar een marktgerichte onderneming die moet concurreren met vergelijkbare ondernemingen. Deze geschiedenis van Het Kantoor heeft belangrijke consequenties voor het functioneren van het personeel. De niet-marktconforme cultuur van het verleden zorgt ervoor dat medewerkers moeten wennen aan de tucht van de markt. Een HRM-functionaris merkt op:

"De gemiddelde werknemer in het bedrijf presteert vooral zorgvuldig en perfect, maar heeft minder oog voor de kosten en de doorlooptijd. Het is nodig om in de komende jaren een betere mix van tijd en werkkwaliteit in te voeren, en dit zal wellicht met wat problemen gepaard gaan. Het invoeren van budgetrestricties veroorzaakt bij sommige werknemers een cultuurschok, maar ook managers zijn nog niet altijd klaar voor de nieuwe cultuur. Evaluatie van bestaande manieren waarop dingen gedaan worden is een essentieel onderdeel van deze nieuwe cultuur."

Deze HRM-functionaris geeft ook aan dat "de omschakeling daar naar toe nogal een 'hell of a job' wordt". Dit is overigens zeker niet alleen te wijten aan de medewerkers; het bedrijf heeft in het verleden soms te weinig accenten gelegd op de ontwikkeling van het menselijk kapitaal van de medewerkers en het bieden van begeleiding bij veranderingen in het werk.

Naast deze overgang naar een marktgerichte onderneming heeft Het Kantoor de laatste jaren met een tweetal andere belangrijke veranderingen te maken gehad. In de eerste plaats heeft in de sector van de financiële dienstverlening de informa- 
tisering met rasse schreden haar intrede gedaan, waardoor het werk van de dossiermedewerkers sterk van karakter is veranderd. Waar eerst gewerkt werd met papieren dossiers loopt nu vrijwel de gehele informatiestroom via de PC. Daarnaast is er ook op het gebied van vakinhoudelijke regelgeving veel veranderd. Omdat de dossiermedewerkers als taak hebben veranderingen in situaties en financiële claims te toetsen aan de regelgeving, is een gedetailleerde kennis van deze regels van groot belang. ledere aanpassing in de bestaande regelgeving brengt dan ook mee dat de kennis van de medewerkers op dit gebied in principe verouderd is en dat men zich moet verdiepen in de nieuwe regels. Een van de directeuren zegt over deze veranderende regelgeving dat "op deze ontwikkelingen vooraf vaak niet al te veel zicht is. Het gebeurt vaak dat bepaalde regelingen na onderhandelingen toch net weer anders uitvallen dan vooraf gedacht". Hij benadrukt dat er steeds meer noodzaak bestaat aan flexibele mensen. "Maar zo is niet iedereen 'gebakken' en dat stelt eisen aan zowel mensen als functies".

Juist omdat Het Kantoor de laatste jaren met zoveel veranderingen is geconfronteerd, is het interessant om de ontwikkelingen in dit bedrijf nader te analyseren. Gezien de turbulente ontwikkelingen kan immers verwacht worden dat een deel van de medewerkers moeite heeft gehad met de vereiste aanpassingen, waardoor mogelijk kennisachterstanden zijn ontstaan. Overigens is om die reden de aandacht voor scholing in Het Kantoor de laatste paar jaar sterk toegenomen, en realiseert het management zich terdege dat de onderneming op de vrije markt alleen goed kan functioneren met een voldoende geschoold personeelsbestand.

In dit rapport zal worden ingegaan op de betekenis die deze veranderingen hebben gehad voor het functioneren van de dossiermedewerkers, de manier waarop men getracht heeft zich aan deze veranderingen aan te passen en de mogelijke kwalificatieproblemen die zich thans nog voordoen. De voornaamste bron voor deze analyse van Het Kantoor is, zoals reeds is aangegeven, een mondelinge enquête die is afgenomen onder een honderdtal dossiermedewerkers en hun managers. Daarnaast hebben ook gesprekken met directeuren en HRM-functionarissen in het bedrijf plaatsgevonden, waarin vooral werd ingegaan op de scholingsactiviteiten van werknemers, de cultuuromslag die nodig is in de overgang van een overheidsinstelling naar een commerciële onderneming en de ontwikkelingen die in de onderneming plaatsvinden. Op basis van deze gesprekken zal in het rapport worden geïllustreerd op welke wijze de staf en het management van Het Kantoor inspeelt op de veranderingen waarmee het bedrijf in het verleden is geconfronteerd en de wijze waarop de medewerkers anticiperen op toekomstige veranderingen.

Dat Het Kantoor een aantal zaken ingrijpend wil veranderen blijkt niet alleen uit die gesprekken, maar ook uit de verbeterde en toegenomen communicatie met de medewerkers over zaken als ziekteverzuim, werkoverleg en prestatiebeloning. Met behulp van op werknemers gerichte informatie wil het management op deze terreinen de bestaande opvattingen en het gedrag veranderen. Ook het expliciet formuleren van productie- en kwaliteitsdoelstellingen behoort tot de nieuwe bedrijfscultuur die het management van Het Kantoor de werknemers eigen wil maken. 


\subsection{Dossiermedewerkers}

In totaal werken er 480 dossiermedewerkers bij de onderzochte eenheid van Het Kantoor. Ongeveer tweederde hiervan zit bij Leven; ongeveer eenderde bij Risico. In het onderzoek zijn van beide bedrijfsonderdelen zo'n 50 personen ondervraagd. Meer dan $20 \%$ van de dossiermedewerkers heeft dus deelgenomen aan het onderzoek.

Tabel 2.1 geeft een overzicht van enkele kenmerken van de ondervraagde groep in vergelijking met de gehele groep dossiermedewerkers bij Het Kantoor. Het blijkt dat in de steekproef vrouwen licht zijn ondervertegenwoordigd, terwijl jongeren behoorlijk zijn oververtegenwoordigd. Als gevolg hiervan ligt het percentage werkenden met een tijdelijk contract in de steekproef hoger en de ervaring en het gemiddelde salaris juist lager. Een belangrijke reden hiervoor is dat in de steekproef ongeveer evenveel medewerkers van beide bedrijfsonderdelen zijn ondervraagd, terwijl in feite bij Leven twee maal zoveel dossiermedewerkers werken als bij Risico . Echter, ook als hiervoor wordt gecorrigeerd blijken vrouwen minder vaak aan de gesprekken te hebben deelgenomen dan mannen en zijn ook de jongeren enigszins oververtegenwoordigd.

Tabel 2.1

Enkele gegevens over alle dossiermedewerkers bij Het Kantoor in vergelijking met de ondervraagde groep

\begin{tabular}{lcc}
\hline & alle dossiermedewerkers & ondervraagde groep \\
\hline Vrouw & $36 \%$ & $32 \%$ \\
Tijdelijk contract & $5 \%$ & $9 \%$ \\
Gehuwd & $67 \%$ & $56 \%$ \\
Leeftijd tot en met 35 & $29 \%$ & $38 \%$ \\
Leeftijd tussen 36 en 45 & $40 \%$ & $35 \%$ \\
Leeftijd boven 45 & $32 \%$ & $39 \%$ \\
Gemiddelde leeftijd & 41 & 14 jaar \\
Jaren in dienst & 17 jaar & fl. 4.318 \\
Salaris (bij volledige werkweek) & fl. 4.492 & \\
\hline
\end{tabular}

Tabel 2.2 gaat in op de verschillen tussen beide bedrijfsonderdelen. Het gaat hier om cijfers over de gehele populatie dossiermedewerkers en dus niet alleen om de ondervraagde medewerkers. Bij Risico werken in vergelijking met Leven meer vrouwen en meer jongeren. Tijdelijke contracten blijken alleen bij Risico voor te komen. Als gevolg van de lagere leeftijd van de medewerkers kent Risico minder gehuwden en is het salaris bij Risico lager dan bij Leven.

Dergelijke gegevens kunnen uiteraard ook per afdeling worden bekeken. Opmerkelijk is dat de gemiddelde leeftijd per afdeling sterk kan variëren van gemiddeld 36 jaar op de jongste afdeling tot 50 op de afdeling met de oudste werknemers. Sommige afdelingen worden dus voornamelijk bemand door ouderen terwijl op andere afdelingen met name jongeren zitten. Of deze ongelijkmatige verdeling het gevolg is van de aard van de werkzaamheden op de verschillende afdelingen, of dat 
de ontstaansgeschiedenis van de afdelingen hier de oorzaak van is, is moeilijk te achterhalen. Als competenties sterk samenhangen met leeftijd betekent dit echter mogelijk wel dat afdelingen beperkt zijn in hun mogelijkheden om taken tussen verschillende personen te verdelen. Daarnaast kan dit ook betekenen dat de ervaringsoverdracht tussen ouderen en jongeren wordt belemmerd, doordat deze medewerkers niet samen op een afdeling zitten.

Tabel 2.2

Enkele gegevens over alle dossiermedewerkers bij Leven in vergelijking met Risico (voor de gehele populatie)

\begin{tabular}{lll}
\hline & Leven & Risico \\
\hline Vrouw & $33 \%$ & $44 \%$ \\
Tijdelijk contract & $0 \%$ & $14 \%$ \\
Gehuwd & $72 \%$ & $57 \%$ \\
Leeftijd tot en met 35 & $21 \%$ & $44 \%$ \\
Leeftijd tussen 36 en 45 & $43 \%$ & $32 \%$ \\
Leeftijd boven 45 & $36 \%$ & $24 \%$ \\
Gemiddelde leeftijd & $42 \%$ & 38 \\
Jaren in dienst & 19 jaar & 12 jaar \\
Salaris & fl. 4.604 & fl. 4.249 \\
\hline
\end{tabular}

De enquête verschaft aanvullende informatie over de dossiermedewerkers. Tabel 2.3 laat zien dat dossiermedewerkers bij Het Kantoor een zeer uiteenlopende opleidingsachtergrond kennen. De grootste groep dossiermedewerkers heeft een MBO-diploma. Echter ook de groepen met MAVO/MULO of HAVONWO als hoogste vooropleiding zijn aanzienlijk. Beide groepen hebben een omvang van meer dan $25 \%$. Daarnaast zijn ook mensen met hoogstens een VBO-kwalificatie of met een $\mathrm{HBO}$ - of WO-diploma werkzaam als dossiermedewerker bij Het Kantoor. Tussen de bedrijfsonderdelen zijn enkele opvallende verschillen zichtbaar. Zo is de groep medewerkers met een MAVO/MULO opleiding bij Leven veel groter dan bij Risico. Het omgekeerde geldt voor de hoogopgeleiden. Deze groep werknemers is juist bij Risico groter.

Tabel 2.3

Dossiermedewerkers naar hun hoogst genoten vooropleiding

\begin{tabular}{lccc}
\hline Opleiding & $\begin{array}{c}\text { Leven } \\
\%\end{array}$ & $\begin{array}{c}\text { Risico } \\
\%\end{array}$ & $\begin{array}{c}\text { Totaal } \\
\%\end{array}$ \\
\hline Geen of VBO & 6 & 12 & 9 \\
MAVO/MULO & 32 & 18 & 25 \\
HAVO/NWO & 20 & 18 & 19 \\
MBO & 30 & 36 & 33 \\
HBO/WO & 12 & 16 & 13 \\
Totaal & 100 & 100 & 100
\end{tabular}




\section{Competenties gemeten: Belang en aanwezigheid}

\subsection{Inleiding}

Om een goed beeld te krijgen van het kennispeil van de medewerkers van Het Kantoor is het allereerst van belang deze competenties waarover de medewerkers beschikken in kaart te brengen. In het onderzoek zijn hiervoor twee wegen bewandeld. In de eerste plaats is aan de betrokken dossiermedewerkers de vraag voorgelegd welke aspecten voor hun functie van belang zijn en hoe zij zelf hun competenties op deze aspecten inschatten. Het gaat hier om een dertiental aspecten die voor de uitvoering van het werk van belang kunnen zijn. Daarnaast hebben we ook aan de managers gevraagd hun medewerkers te beoordelen. Aan hen is de vraag voorgelegd om aan iedere medewerker een algemene beoordeling te geven voor de wijze waarop men de functie uitoefent. Daarnaast hebben zij ook een cijfer van 1 tot 10 gegeven voor een zevental aspecten van het werk die ook aan de medewerkers zijn voorgelegd.

\subsection{Het oordeel van de medewerkers}

Zoals is opgemerkt, is in het onderzoek bij Het Kantoor voor een dertiental aspecten van het werk aan de dossiermedewerkers gevraagd hoe belangrijk deze zijn voor het werk dat zij verrichten. Tabel 3.1 geeft hiervan een beeld.

Tabel 3.1

Gemiddeld belang van verschillende facetten voor de uitoefening van het werk in volgorde van belang (vijfpuntsschaal van $1 \mathrm{t} / \mathrm{m} 5$ )

\begin{tabular}{lc}
\hline Facet & score \\
\hline Computer & 4,7 \\
Nauwkeurigheid & 4,5 \\
Eenvoudige berekeningen & 4,3 \\
Probleemherkenning & 4,3 \\
Adviseren klanten & 4,3 \\
Problemen uitzoeken & 4,1 \\
Vakkennis & 3,9 \\
Team work & 3,9 \\
Instrueren & 3,8 \\
Plannen & 3,8 \\
Lezen & 3,6 \\
Schrijven & 2,6 \\
Complexe berekeningen & 2,2 \\
\hline
\end{tabular}

Bovenaan in deze lijst staan werken met de computer, nauwkeurig werken en uitvoeren van berekeningen zoals optellen en vermenigvuldigen. Ver beneden de elf andere activiteiten sluiten schrijven en meer geavanceerde wiskundige en statistische procedures de lijst af. Ouderen blijken bijna alle facetten in de lijst minder belangrijk te vinden dan jongeren. De enige uitzondering hierop is het belang van vakkennis dat door de ouderen juist hoger wordt aangeslagen. Dit kan het 
gevolg zijn van het feit dat oudere werknemers veelal al bij Het Kantoor werkten in de tijd dat vakkennis nog het belangrijkste aspect in het functioneren was. Hoger opgeleiden blijken daarentegen bijna alle facetten belangrijker te vinden dan lager opgeleiden. De enige uitzonderingen hier zijn opnieuw vakkennis, maar ook gebruik maken van de computer. Deze twee facetten worden juist door lager opgeleiden belangrijker geacht.

De dossiermedewerkers is ook gevraagd een beoordeling te geven van hun eigen functioneren op deze dertien aspecten. Deze cijfers staan weergegeven in tabel 3.2. De eigen beoordelingen lopen behoorlijk uiteen tussen de verschillende items. De dossiermedewerkers geven zichzelf de hoogste beoordelingen voor team work, eenvoudige berekeningen en computerkennis. De laagste beoordelingen zijn voor complexe berekeningen, schrijven en instrueren. De tabel laat zien dat de verschillen tussen Leven en Risico zeer gering zijn. Opmerkelijk is dat ouderen zichzelf in alles beter blijken te vinden dan jongeren. Alleen team work en werken met computers gaat hen naar eigen zeggen minder goed af. Achter deze leeftijd kan echter ook ervaring schuil gaan. Uit een nadere analyse blijkt dat voor adviseren, lezen en schrijven vooral de totale tijd dat een medewerker werkzaam is bij Het Kantoor van invloed is op de eigen beoordeling, terwijl voor team work, vakkennis en rekenen vooral de duur in de huidige functie bepalend is.

Tabel 3.2

Eigen beoordeling op een dertiental facetten (vijfpuntsschaal van $1 \mathrm{t} / \mathrm{m} 5$ )

\begin{tabular}{lccc}
\hline Facet & Leven & Risico & Totaal \\
\hline Nauwkeurigheid & & & \\
Instrueren & 4,2 & 4,1 & 4,1 \\
Adviezen klanten & 3,1 & 3,0 & 3,1 \\
Team work & 3,9 & 3,8 & 3,8 \\
Vakkennis & 4,4 & 4,4 & 4,4 \\
Computer & 3,7 & 3,6 & 3,7 \\
Probleemherkenning & 4,0 & 4,1 & 4,1 \\
Problemen uitzoeken & 3,8 & 3,5 & 3,7 \\
Plannen & 3,5 & 3,2 & 3,4 \\
Lezen & 4,0 & 3,9 & 4,0 \\
Schrijven & 3,4 & 3,5 & 3,5 \\
Eenvoudige berekeningen & 2,7 & 2,6 & 2,6 \\
Complexe berekeningen & 4,3 & 4,2 & 4,3 \\
& 1,7 & 1,8 & 1,8 \\
\hline
\end{tabular}

\subsection{Het oordeel van de managers}

In het onderzoek is ook aan de managers van de dossiermedewerkers gevraagd een oordeel uit te spreken over de kwaliteit van de betrokkenen. Het gaat hier om een algemene beoordeling en om een cijfer voor zeven specifieke facetten. De beoordelingen vonden plaats op een tienpuntsschaal van 1 tot 10.

Tabel 3.3 geeft een overzicht van de oordelen van de managers over hun medewerkers. Opmerkelijk is dat gemiddelde cijfers die de medewerkers van hun managers krijgen niet erg uiteenlopen. Deze cijfers geven - in tegenstelling tot de 
beoordelingen van de betrokkenen zelf - nauwelijks een beeld van waar medewerkers bij Het Kantoor over het algemeen goed in zijn. De managers blijken overigens het meest te spreken te zijn over het rekenen van hun medewerkers, het minst over hun schrijfkwaliteiten. In tegenstelling tot de eigen beoordeling blijken managers dossiermedewerkers van Risico bijna altijd hoger aan te slaan dan dossiermedewerkers van Leven. Dit komt doordat het opleidingsniveau bij Leven gemiddeld lager ligt en deze groep de eigen competenties relatief hoog inschat, vergeleken met het oordeel van de manager. Alleen met betrekking tot schrijven zijn de managers gemiddeld meer te spreken over dossiermedewerkers bij Leven dan bij Risico. Met name voor instrueren en computervaardigheden krijgen de medewerkers bij Risico een hoger gemiddeld oordeel dan de medewerkers bij Leven. Dit spoort met het feit dat deze zaken bij Risico door de afdelingshoofden als belangrijker wordt gezien.

Tabel 3.3

Beoordeling door managers van de dossiermedewerkers in het algemeen en op een zevental facetten (tienpuntsschaal)

\begin{tabular}{lccc}
\hline Facet & Leven & Risico & Totaal \\
\hline Algemeen & 7,3 & 7,4 & 7,4 \\
Instrueren & 6,7 & 7,4 & 7,0 \\
Adviezen klanten & 7,4 & 7,6 & 7,5 \\
Vakkennis & 7,3 & 7,5 & 7,4 \\
Computervaardigheden & 7,1 & 7,7 & 7,4 \\
Planning & 7,2 & 7,3 & 7,3 \\
Schrijven & 6,9 & 6,5 & 6,8 \\
Rekenen & 7,7 & 7,7 & 7,7 \\
& & & \\
\hline
\end{tabular}

Tabel 3.4 gaat in op de verschillen tussen mannen en vrouwen in de beoordeling van het afdelingshoofd. Hoewel het algemene oordeel over mannen iets gunstiger is, krijgen vrouwen bij specifieke facetten doorgaans een betere beoordeling van hun manager dan mannen. Het verschil is het grootst bij instrueren. Deels hangen deze verschillen samen met het feit dat vrouwen gemiddeld hoger opgeleid en jonger zijn dan mannen, maar zelfs als voor deze invloeden wordt gecorrigeerd blijft er verschil bestaan. Alleen voor computervaardigheden krijgen mannen een hoger punt dan vrouwen.

Tabel 3.4

Beoordeling door managers van mannen en vrouwen in het algemeen en op een zevental facetten (tienpuntsschaal)

\begin{tabular}{lcc}
\hline Facet & Man & Vrouw \\
\hline Algemeen & 7,4 & 7,3 \\
Instrueren & 6,8 & 7,5 \\
Adviezen klanten & 7,4 & 7,7 \\
Vakkennis & 7,4 & 7,4 \\
Computervaardigheden & 7,4 & 7,3 \\
Planning & 7,2 & 7,3 \\
Schrijven & 6,7 & 7,7 \\
Rekenen & 7,7 & \\
\hline
\end{tabular}


Tabel 3.5 zoomt in op het opleidingsniveau. VBO'ers krijgen als enige gemiddeld een onvoldoende uitgereikt door de managers. Dat betreft instrueren. De beoordeling loopt meestal duidelijk op met de opleidingsachtergrond. Alleen MBO scoort vaak lager dan HAVO. Een uitzondering hierop vormen de computervaardigheden, die voor MBO'ers hoger worden ingeschat dan voor Havisten.

Tabel 3.5

Beoordeling door managers van de dossiermedewerkers per opleidingsniveau, in het algemeen en op een zevental facetten (tienpuntsschaal)

\begin{tabular}{|c|c|c|c|c|c|}
\hline Facet & VBO & MAVO & HAVO & MBO & HBONO \\
\hline $\begin{array}{l}\text { Algemeen } \\
\text { Instrueren } \\
\text { Adviezen klanten } \\
\text { Vakkennis } \\
\text { Computervaardigheden } \\
\text { Planning } \\
\text { Schrijven } \\
\text { Rekenen }\end{array}$ & $\begin{array}{l}6,8 \\
4,8 \\
6,7 \\
6,1 \\
6,3 \\
6,9 \\
5,8 \\
6,9\end{array}$ & $\begin{array}{l}7,3 \\
6,4 \\
7,2 \\
7,5 \\
7,1 \\
7,3 \\
6,4 \\
7,5\end{array}$ & $\begin{array}{l}7,6 \\
7,9 \\
7,9 \\
7,8 \\
7,3 \\
7,5 \\
7,1 \\
7,8\end{array}$ & $\begin{array}{l}7,4 \\
7,3 \\
7,5 \\
7,4 \\
7,8 \\
7,1 \\
6,9 \\
7,8\end{array}$ & $\begin{array}{l}7,7 \\
7,8 \\
7,9 \\
7,5 \\
7,6 \\
7,5 \\
7,7 \\
8,3\end{array}$ \\
\hline
\end{tabular}

Tabel 3.6 laat zien dat meestal de dossiermedewerkers tussen 35 en 45 de hoogste beoordeling krijgen. Alleen voor computervaardigheden blijken jongeren een hogere beoordeling te krijgen dan de groep van 36 tot 45 .

Tabel 3.6

Beoordeling door managers van de dossiermedewerkers per leeftijdsgroep, in het algemeen en op een zevental facetten (tienpuntsschaal)

\begin{tabular}{lccc}
\hline Aspect & -35 & $36-45$ & $46+$ \\
\hline Algemeen & & & \\
Instrueren & 7,4 & 7,6 & 7,0 \\
Adviezen Klanten & 7,7 & 7,7 & 5,4 \\
Vakkennis & 7,6 & 7,7 & 7,1 \\
Computervaardigheden & 7,5 & 7,7 & 6,9 \\
Planning & 8,0 & 7,3 & 6,6 \\
Schrijven & 7,3 & 7,4 & 7,0 \\
Rekenen & 6,9 & 7,2 & 6,2 \\
& 7,9 & 7,9 & 7,1 \\
\hline
\end{tabular}

Door de waarderingen voor de zeven specifieke aspecten te relateren aan de algemene waardering door de baas van een dossiermedewerker ontstaat een beeld van wat een manager belangrijk vindt in het werk van de dossiermedewerkers. Deze waarderingen worden gepresenteerd in tabel 3.7. De tabel laat zien met hoeveel punten de algemene waardering van de manager toeneemt als zijn waardering voor een specifiek aspect met één punt toeneemt. Voor Het Kantoor als geheel blijkt planning de belangrijkste factor te zijn in de beoordeling van de medewerkers, gevolgd door vakkennis en rekenen. Daarnaast spelen ook schrijven en het adviseren van klanten een rol in de waardering die de dossiermedewerkers krijgen van hun manager. Er blijken echter opmerkelijke verschillen te bestaan tussen de beoordeling van managers bij de bedrijfsonderdelen Leven en Risico. Opmerkelijk 
genoeg blijkt het oordeel van de manager over vakkennis bij Risico slechts een kleine invloed te hebben op het totaaloordeel. Rekenen en planning zijn hier veel belangrijker. Dossiermedewerkers die in de ogen van hun manager goed zijn in het adviseren van klanten krijgen bij Risico geen beter algemeen oordeel.

Tabel 3.7

Belang van een zevental aspecten in de totaalbeoordeling van de dossiermedewerkers door hun manager (gemiddelde extra algemene waardering per extra punt waardering op genoemde aspecten)

\begin{tabular}{lccc}
\hline Aspect & Leven & Risico & Totaal \\
\hline Instrueren & - & - & - \\
Klanten adviseren & 0,31 & - & 0,10 \\
Vakkennis & 0,41 & 0,14 & 0,27 \\
Computervaardigheden & $-\overline{-}$ & $-\overline{54}$ & $-\overline{42}$ \\
Planning & $0,-$ & - & 0,14 \\
Schrijven & 0,16 & 0,43 & 0,27 \\
Rekenen & & & \\
\hline
\end{tabular}

Als de inschattingen van dossiermedewerkers zelf worden gerelateerd aan het algemene oordeel van hun manager blijkt dat medewerkers die zichzelf beter vinden in achtereenvolgens plannen, rekenen en vakkennis ook een beter oordeel van hun manager krijgen. Ook medewerkers die zeggen goed te zijn in het adviseren van klanten blijken een hogere waardering te krijgen. Zeer opmerkelijk is dat dossiermedewerkers die aangeven dat ze over veel computervaardigheden beschikken, door hun manager juist veel lager worden beoordeeld, dan medewerkers die dit niet aangeven. Overigens is de samenhang tussen de inschattingen van de medewerkers en het algemene oordeel van de manager uiteraard veel zwakker dan de samenhang tussen de inschattingen van de managers zelf op de diverse onderdelen en zijn totaalinschatting. Verderop in dit hoofdstuk zal nog dieper worden ingegaan op de verschillen tussen de beoordeling van de manager en zijn medewerkers. Als zowel de beoordeling van de managers als die van de dossiermedewerkers zelf, gezamenlijk worden gerelateerd aan het algemene oordeel van de manager, blijkt alleen nog de mening van de medewerker over zijn kwaliteiten met betrekking tot rekenen een duidelijke positieve invloed te hebben. Dit lijkt er op te wijzen dat de medewerker veel beter dan zijn manager in staat is om zijn capaciteiten op dit gebied te waarderen en als afzonderlijke component van zijn algehele functioneren te identificeren.

Vanuit een economisch perspectief zou verwacht mogen worden dat medewerkers die over competenties beschikken die door de manager worden gewaardeerd, ook een hoger salaris hebben als reflectie van deze waardering. In tabel 3.8 wordt gekeken naar de effecten die de waardering van de manager heeft op het salaris van de dossiermedewerkers. Naast de aspecten die in de tabel zijn opgenomen is hierbij gecorrigeerd voor leeftijd, opleidingsniveau en ervaring. Uit de tabel komen twee zaken naar voren. Allereerst blijkt de waardering in de vorm van het salaris niet geheel te sporen met de waardering zoals die geuit is door de manager. Voor Het 
Kantoor als geheel blijken met name de waardering voor instrueren en schrijven een positief effect op de beloning te hebben, terwijl deze aspecten slechts een ondergeschikte rol bij de waardering door de manager spelen. Computervaardigheden blijken zelfs negatief met het salaris samen te hangen. Daarnaast blijken er grote verschillen te zijn tussen Leven en Risico. Bij Leven vallen vooral de sterk negatieve invloed van computervaardigheden en de hoge positieve invloed van vakkennis op het salaris op. Bij Risico speelt maar één aspect een rol: Een goede beoordeling voor rekenen wordt positief beloond.

Tabel 3.8

Variatie in maandsalaris van de dossiermedewerkers als gevolg van waardering van de manager (gemiddeld extra salaris in guldens per punt extra waardering)

\begin{tabular}{lrrr}
\hline Aspect & Leven & Risico & Totaal \\
\hline Instrueren & 150 & - & 76 \\
Klanten adviseren & -134 & - & - \\
Vakkennis & 192 & - & -155 \\
Computervaardigheden & -251 & - & - \\
Planning & 148 & - & - \\
Schrijven & - & 165 & - \\
Rekenen & & & \\
\hline
\end{tabular}

Naast het salaris ontvangen sommige medewerkers op één of meerdere tijdstippen in het jaar een gratificatie. Net zoals bij het salaris het geval was, mag verwacht worden dat het oordeel van de manager over de competenties van de medewerkers van invloed is op hoogte van het gratificatiebedrag. Het gratificatiebedrag bestaat uit alle in 1998 en 1999 ontvangen gratificaties. $\mathrm{Er}$ is gekozen voor een periode van twee jaar om zo te corrigeren voor al te grote toevalligheden in de gegevens. Daarom is de analyse in tabel 3.8 ook ingevoerd voor het gratificatiebedrag. De resultaten daarvan zijn terug te vinden in tabel 3.9. Ook hier is gecorrigeerd voor leeftijd, opleidingsniveau en ervaring.

Tabel 3.9

Gratificaties van de dossiermedewerkers als gevolg van waardering van de manager (gemiddeld extra gratificatie in guldens per punt extra waardering)

\begin{tabular}{lrrr}
\hline Aspect & Leven & Risico & Totaal \\
\hline Instrueren & 971 & - & 415 \\
Klanten adviseren & 789 & 117 & 233 \\
Vakkennis & 691 & - & - \\
Computervaardigheden & -592 & -224 & -322 \\
Planning & 473 & $-\overline{-}$ & 554 \\
Schrijven & - & 281 & 334 \\
Rekenen & & & \\
\hline
\end{tabular}

De tabel laat zien dat medewerkers van Leven gemiddeld een hogere gratificatie ontvangen als ze door hun manager beter worden beoordeeld op het vlak van instrueren, klanten adviseren, vakkennis en schrijvers. Planningsvaardigheden 
hebben een negatief effect op de hoogte van de gratificatie, een resultaat dat ook geldt voor de Risico-medewerkers. Voor deze groep werkt het managersoordeel voor klanten adviseren en rekenen gratificatieverhogend.

Wanneer de resultaten uit tabel 3.9 worden vergeleken met de gegevens in tabel 3.8 waarin het verband tussen managersoordeel en salaris werd bekeken blijkt dat gratificaties veel sterker samenhangen met de competenties van de medewerkers dan de reguliere beloning. Dat duidt erop dat de gratificaties veel sterker een waardering zijn voor de wijze waarop het werk wordt uitgeoefend dan het reguliere salaris. Opnieuw blijkt de relatie tussen managersoordeel en beloning bij Leven beter ontwikkeld te zijn dan bij Risico. De gratificaties van medewerkers hangen ook veel sterker samen met het algemene managersoordeel over medewerkers dan de salarissen. Tussen salarissen en dit algemene oordeel bestaat geen correlatie, terwijl de correlatie tussen gratificaties en het algemene oordeel bijna 0.4 bedraagt.

\subsection{Beoordeling managers versus medewerkers}

Uit voorafgaande beschrijvingen blijkt dat de oordelen over competenties tussen manager en medewerker niet altijd parallel lopen. In tabel 3.10 wordt globaal aangegeven welke samenhang er bestaat tussen de algemene beoordeling en de zeven specifieke beoordelingen van de manager en de mening van de medewerker zelf over een dertiental aspecten van zijn werk. De samenhang tussen de oordelen van de managers en de dossiermedewerkers bij Het Kantoor is niet bijzonder sterk. Alleen bij team work, probleemuitzoeken en rekenen wordt een sterk verband gevonden.

Ook is opmerkelijk dat de waarderingen van de dossiermedewerkers en de managers met betrekking tot dezelfde kenmerken niet altijd samenhangen. Het betreft hier de grijze vakken in de tabel. Voor instrueren, adviseren, wordt het verwachte verband niet aangetroffen. Met name de beoordeling op het gebied van vakkennis, maar ook voor schrijven en rekenen door de manager, blijkt samen te hangen met de eigen inschatting met betrekking tot een groot aantal werkaspecten door de medewerker. Dit zou er op kunnen wijzen dat de manager de performance van de medewerker sterk als een geheel beschouwt en kennelijk niet goed in staat is om afzonderlijke dimensies hierin te onderkennen.

Omgekeerd lijkt uit de gebrekkige samenhang tussen het oordeel van de medewerker zelf en zijn manager naar voren te komen dat ook de medewerkers zelf geen adequaat beeld hebben van hun eigen capaciteiten. Zowel mispercepties met betrekking tot de capaciteiten door de manager, als door de dossiermedewerkers zelf kunnen belangrijke belemmeringen zijn voor beleid gericht op competentieontwikkeling. Als medewerkers en hun managers immers niet goed weten wat de sterke en de zwakke punten zijn is het ook moeilijk om adequate keuzes te maken met betrekking tot de verdere ontwikkeling. Dit werd ook opgemerkt door een directeur die zei dat "de allereerste stap van het opleidingsplan een competentiemeting van werknemers is via gesprekken met de medewerkers. Hier komt een 
competentie- en een opleidingsbehoefteprofiel uit". Alleen met zo'n profiel lijkt het hem zinvol om na te denken over de verdere competentie-ontwikkeling van de medewerkers.

\section{Tabel 3.10}

Het eigen oordeel over het functioneren van een dossiermedewerker vergeleken met het oordeel van zijn manager

\begin{tabular}{|c|c|c|c|c|c|c|c|c|}
\hline medewerker & 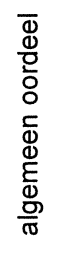 & 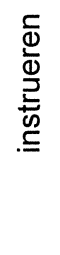 & 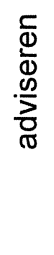 & 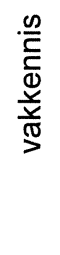 & 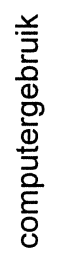 & $\begin{array}{l}\frac{c}{\Phi} \\
\stackrel{0}{\frac{1}{0}} \\
\frac{\mathbb{0}}{0}\end{array}$ & 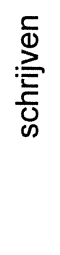 & 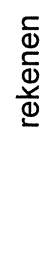 \\
\hline nauwkeurig werken & & & & & & & & \\
\hline instrueren & & & & & & & & \\
\hline adviseren & & & & ++ & & & & \\
\hline team work & & & - & ++ & & & ++ & - \\
\hline vakkennis & + & & & + & - & & & - \\
\hline computergebruik & - & & & & (4t) & & & \\
\hline constateren problemen & & & & + & & & & \\
\hline problemen uitzoeken & & - & & ++ & & & & \\
\hline plannen & & & & ++ & -- & +4 & & - \\
\hline lezen & + & & -- & & & & ++ & -- \\
\hline schrijven & & + & & & & & +1 & -- \\
\hline rekenen & ++ & ++ & & & & & & \\
\hline wiskunde & & - & & & & & & + \\
\hline
\end{tabular}




\section{De allocatie van arbeid}

\subsection{Inleiding}

Om een bedrijf goed te laten functioneren dienen de taken die mensen uitoefenen in overeenstemming te zijn met de competenties waarover de medewerkers beschikken. Als er zich competentieproblemen voordoen zijn er in principe dan ook twee oplossingen denkbaar: of de medewerker past zijn competenties aan, of het bedrijf past de werkzaamheden aan die de betrokkene moet verrichten. In het vorige hoofdstuk is uitvoerig ingegaan op de competenties waarover de dossiermedewerkers die bij Het Kantoor werken beschikken. In dit hoofdstuk wordt in aansluiting daarop de allocatie van het werk onder de loep genomen. Allereerst wordt hierbij gekeken naar de werktijd en overwerk. Vervolgens komt de taakverdeling aan bod.

\subsection{Werktijd en overwerk}

Allereerst is het van belang om na te gaan in hoeverre de competenties waarover mensen beschikken van invloed zijn op de hoeveelheid werk die men verricht. Het overgrote deel van de dossiermedewerkers heeft een full-time aanstelling. Slechts $13 \%$ werkt minder dan 36 uur per week. Tabel 4.1 laat zien dat de dossiermedewerkers naar eigen zeggen gemiddeld zo'n twee uur per week meer dan hun contractuele arbeidsduur werken. Bij Leven wordt minder overgewerkt dan bij Risico (2,0 uur versus 2,4 uur), terwijl mannen (2,4 uur) weer meer overwerken dan vrouwen (1,9 uur). Voor mensen met hoogstens een VBO-opleiding of een MAVO/MULO-diploma ligt dit gemiddelde net beneden de twee uur, terwijl het voor de hoger opgeleiden net boven de twee uur ligt. Tabel 4.2 laat zien dat de jongeren en de ouderen het langste werken. In de leeftijdsgroep tussen 36 en 45 jaar bedraagt het overwerk gemiddeld slechts 1,6 uur per week. Het blijkt wel dat het overwerk voor deze leeftijdsgroep sterk geconcentreerd is bij de Leven medewerkers, die gemiddeld 2,2 uur overwerken. Voor de oudere werknemers geldt dat juist binnen Risico meer wordt overgewerkt dan bij Leven.

Tabel 4.1

Gemiddeld aantal uren overwerk per week per opleidingsniveau

\begin{tabular}{lccc}
\hline Opleidingsniveau & Leven & Risico & Totaal \\
\hline Geen of VBO & 1,3 & 2,0 & 1,8 \\
MAVO/MULO & 1,7 & 1,4 & 1,6 \\
HAVO/NWO & 2,3 & 2,7 & 2,5 \\
MBO & 2,7 & 2,5 & 2,6 \\
HBO/WO & 1,0 & 3,3 & 2,5 \\
Totaal & 2,0 & 2,4 & 2,2 \\
\hline
\end{tabular}

Het is ook bekend hoe lang de interviews met de dossiermedewerkers hebben geduurd. Opmerkelijk is dat degenen bij wie de gesprekken langer duurden dan men 
zou verwachten ook meer overwerken dan degenen die juist sneller dan verwacht het interview voltooiden. Het gaat hier om 2,5 uur versus 1,9 uur overwerk per week. Wellicht kan dit verklaard worden uit het feit dat mensen die langer over hun gesprek doen, ook in dagelijkse werkzaamheden wat langzamer zijn, waardoor ze meer moeten overwerken om hun werk af te kunnen krijgen.

Tabel 4.2

Gemiddeld aantal uren overwerk per week per leeftijdsgroep

\begin{tabular}{lccc}
\hline Leeftijd & Leven & Risico & Totaal \\
\hline-35 & 1,8 & 2,9 & 2,5 \\
$36-45$ & 2,2 & 0,9 & 1,6 \\
$46+$ & 2,0 & 3,9 & 2,7 \\
Totaal & 2,0 & 2,4 & 2,2 \\
\hline
\end{tabular}

Tabel 4.3

Samenhang tussen beoordeling door het afdelingshoofd en overwerk door de medewerkers

\begin{tabular}{lc}
\hline Werkaspect & extra uren overwerk per week per punt waardering \\
\hline Algemeen & $-1,1$ \\
Instrueren & $-1,4$ \\
Adviseren & 1,1 \\
Vakkennis & 2,0 \\
Computer & 0,1 \\
Plannen & 0,2 \\
Schrijven & $-0,1$ \\
Rekenen & 0,0 \\
\hline
\end{tabular}

Overwerk blijkt inderdaad sterk samen te hangen met de competenties waarover mensen beschikken. Daarbij is overigens niet a priori duidelijk welke relaties hier bestaan. Het kan bijvoorbeeld zo zijn dat de mensen met een tekort aan bepaalde competenties dit compenseren door over te werken, maar het is ook mogelijk dat juist die medewerkers die erg goed zijn, door het bedrijf extra taken toegewezen krijgen, met als gevolg dat juist die mensen meer overwerken. Tabel 4.3 laat zien in welke mate het overwerk samenhangt met de beoordelingen die managers hen geven voor de verschillende aspecten van het werk. Dossiersmedewerkers die een betere algemene beoordeling krijgen, werken minder uren over. Een duidelijk negatief effect gaat ook uit van goed zijn in instrueren. Mensen met veel vakkennis blijken daarentegen juist veel over te werken. Het lijkt er dus op dat juist deze medewerkers een extra hoeveelheid werk krijgen toebedeeld, juist omdat ze over deze vakkennis beschikken.

Als overwerk wordt gerelateerd aan de beoordeling die de dossiermedewerkers zelf geven voor de genoemde aspecten van het werk, dan blijken degenen die zeggen goed te kunnen plannen juist langer over te werken. Dit geldt ook voor dossiermedewerkers die volgens eigen opgave goed zijn in schrijven. Medewerkers die goed zijn in rekenen werken daarentegen juist aanzienlijk minder over dan hun 
collega's. Het sterke effect van vakkennis en instrueren komt bij de eigen beoordelingen niet meer naar voren.

\subsection{Werkzaamheden en taakverdeling}

Aan de dossiermedewerkers is ook gevraagd uit welke werkzaamheden hun werk bestaat. Doordat deze vraag open werd gesteld deelde niet iedereen de werkzaamheden op een vergelijkbare manier in. Tabel 4.4 geeft een beeld van de antwoorden die hierbij werden gegeven. Toekennen en berekenen zijn de meest genoemde werkzaamheden. Zij werden door respectievelijk $52 \%$ en $62 \%$ van de dossiermedewerkers genoemd. Ook corresponderen, inlichten en begeleiding van medewerkers werden vaak als werkzaamheid genoemd. Uit analyse van de antwoorden blijkt dat corresponderen, inlichten, begeleiding medewerkers, verificatie en overig - dat bestaat uit eenmalige specifieke werkzaamheden en assistentie bij het leidinggeven, zoals werkverdelen - vaak door medewerkers als beheerswerkzaamheden worden gezien. Ondervraagden die beheerswerkzaamheden expliciet noemen blijken veel minder ook nog een van deze vijf afzonderlijke werkzaamheden te noemen. Uit een vergelijkbare analyse blijkt dat inlichten en overig door een aantal dossiermedewerkers mee wordt gerekend bij toekennen.

De tabel geeft ook een beeld van de hoeveelheid tijd die met de genoemde werkzaamheden is gemoeid. Hierbij zijn alle antwoorden teruggerekend naar een werkweek van 36 uur. De hoeveelheid tijd die gemiddeld aan de activiteiten wordt besteed loopt sterk uiteen. Voor een groot deel is deze variatie het gevolg van het feit dat niet iedereen alle werkzaamheden noemt. De laatste kolom van tabel 4.3 laat daarom zien hoeveel tijd deze werkzaamheden gemiddeld kosten bij de dossiermedewerkers die de betreffende werkzaamheid expliciet hebben genoemd. Toekennen, berekenen, beheerswerkzaamheden en verificatie blijken de meeste tijd te kosten. De verschillen met de andere activiteiten zijn echter beperkt.

Ook de variatie in bestede tijd is vrijwel gelijk voor alle genoemde werkzaamheden. De variatie bij toekennen en beheerswerkzaamheden is iets groter dan bij de andere werkzaamheden. De grootste verschillen in bestede uren zijn daardoor het gevolg van het feit dat bepaalde medewerkers bepaalde activiteiten überhaubt niet verrichten. Hierbij is het overigens de vraag of zij ook daadwerkelijk andere activiteiten verrichten of dat zij dit werk alleen anders benoemen.

Als de werkzaamheden in drie hoofdcategorieën worden verdeeld ontstaat het volgende beeld. $33 \%$ van de tijd wordt besteed aan berekeningen, $53 \%$ aan beheerswerkzaamheden en $14 \%$ aan sturing. 
Tabel 4.4

Frequentie waarmee bepaalde werkzaamheden worden genoemd en de gemiddelde tijd besteed aan deze werkzaamheden door alle dossiermedewerkers en door alleen degenen die de betreffende activiteit hebben genoemd (bij een 36-urige werkweek)

\begin{tabular}{lccc}
\hline Werkzaamheid & Frequentie \% & $\begin{array}{l}\text { Gemiddeld } \\
\text { aantal uren alle } \\
\text { medewerkers }\end{array}$ & $\begin{array}{l}\text { Gemiddeld aantal uren } \\
\text { voor zover werkzaam- } \\
\text { heden genoemd }\end{array}$ \\
\hline Toekennen & 52 & 8,2 & 16 \\
Berekenen & 7 & 1,4 & 20 \\
Beheerswerkzaamheden & 62 & 12,1 & 19,7 \\
Vergaderen & 2 & 0,2 & 7,5 \\
Corresponderen & 24 & 3 & 12,4 \\
Inlichten & 26 & 3,7 & 14 \\
Begeleiding medewerkers & 15 & 1,9 & 18,7 \\
Verificatie & 11 & 2,1 & 16,8 \\
Overig & 18 & 3 & 36 \\
Totaal & & 36 & \\
\hline
\end{tabular}

Tabel 4.5 geeft aan in hoeverre de werkzaamheden van dossiermedewerkers bij Leven verschillen van die bij Risico. Bij Risico blijkt de gemiddelde dossiermedewerker veel meer tijd te besteden aan beheerswerkzaamheden, maar bij Leven wordt dit gecompenseerd door de tijd die wordt besteed aan activiteiten zoals berekenen, corresponderen, verificatie en overig. Bij Risico wordt gemiddeld meer tijd gestoken in de begeleiding van medewerkers. Opvallend is hierbij dat het aantal medewerkers dat begeleiding noemt als een expliciete activiteit juist bij Leven twee maal zo hoog is als bij Risico. Het lijkt er dus op dat een kleine groep medewerkers bij Risico een relatief zware begeleidingstaak heeft, terwijl de begeleidingswerkzaamheden bij Leven sterker verspreid zijn.

Als weer gekeken wordt naar de drie hoofdcategorieën dan blijken berekeningen bij Leven $42 \%$ van de tijd in beslag te nemen, terwijl dit bij Risico slechts $25 \%$ is. Beheerswerkzaamheden kosten bij Leven $42 \%$ van de tijd en bij Risico $62 \%$. Sturing blijkt bij Leven $16 \%$ van de tijd in beslag te nemen, terwijl dit bij Risico $13 \%$ is.

Tabel 4.5

De gemiddelde tijd besteed aan werkzaamheden bij Leven en Risico, door alle dossiermedewerkers (bij een 36-urige werkweek)

\begin{tabular}{lcc}
\hline Werkzaamheid & Leven & Risico \\
\hline Toekennen & 8,2 & 8,2 \\
Berekenen & 2,5 & 0,3 \\
Beheerswerkzaamheden & 7,5 & 16,7 \\
Vergaderen &,- 1 & 0,3 \\
Corresponderen & 3,1 & 3,8 \\
Inlichten & 1,3 & 2,2 \\
Begeleiding medewerkers & 3,8 & 0,6 \\
Verificatie & 4,4 & 1,8 \\
Overig & & \\
\hline
\end{tabular}


Het valt te verwachten dat de werkzaamheden die mensen verrichten samenhangen met de competenties waarover zij beschikken. Tabel 4.6 geeft een overzicht van de kenmerken van degenen die juist wel of juist niet een bepaalde werkzaamheid uitoefenen. Degenen met een hoge algemene waardering door de manager blijken vaak toekennen en berekenen als werkzaamheid op te geven. Bij een lage algehele waardering is de kans juist groot dat men wordt ingezet bij verificatie of de categorie overige, die bestaat uit speciale eenmalige klussen en hulp bij het leidinggeven. Het gaat hierbij overigens niet per se om mensen met lage capaciteiten. Degenen die verificatie-werkzaamheden verrichten zijn volgens hun manager goed in plannen en rekenen, terwijl de overige werkzaamheden worden uitgevoerd door medewerkers die opvallen vanwege hun vakkennis, schrijfvaardigheden en vaak een hogere opleiding hebben. Kennelijk worden voor deze specifieke werkzaamheden mensen ingezet die ook op specifieke aspecten hun talent hebben. Wellicht scoren zij op andere onderdelen minder waardoor hun algemene waardering toch lager blijft.

Tabel 4.6

Factoren die van invloed zijn op de kans een bepaalde werkzaamheid uit te voeren

\begin{tabular}{|c|c|c|}
\hline Werkzaamheid & Meer uitgeoefend door: & Minder uitgeoefend door: \\
\hline Toekennen & $\begin{array}{l}\text { - hoge algemene waardering } \\
\text { - mannen } \\
\text { - lager opgeleiden } \\
\text { - jongeren }\end{array}$ & $\begin{array}{l}\text { - hoge score } \\
\text { computervaardigheden } \\
\text { - hoge score plannen }\end{array}$ \\
\hline Berekenen & $\begin{array}{l}\text { - hoge algemene waardering } \\
\text { - hoge score instrueren } \\
\text { - vrouwen }\end{array}$ & $\begin{array}{l}\text { - hoge score adviseren } \\
\text { - hoge score vakkennis }\end{array}$ \\
\hline Beheerswerkzaamheden & $\begin{array}{l}\text { - hoge score adviseren } \\
\text { - hoge score rekenen }\end{array}$ & $\begin{array}{l}\text { - hoge score } \\
\text { computervaardigheden }\end{array}$ \\
\hline Corresponderen & $\begin{array}{l}\text { - hoge score instrueren } \\
\text { - hoge score plannen } \\
\text { - MAVO/MULO of HAVO/VWO }\end{array}$ & - hoge score adviseren \\
\hline Inlichten & $\begin{array}{l}\text { - hoge score } \\
\text { computervaardigheden } \\
\text { - geen diploma of VBO } \\
\text { - vrouwen } \\
\text { - jongeren }\end{array}$ & - hoge score instrueren \\
\hline Begeleiding & $\begin{array}{l}\text { - hoge score adviseren } \\
\text { - hoge score vakkennis } \\
\text { - lager opgeleiden }\end{array}$ & - hoge score plannen \\
\hline Verificatie & $\begin{array}{l}\text { - hoge score plannen } \\
\text { - hoge score rekenen } \\
\text { - MAVO/MULO }\end{array}$ & $\begin{array}{l}\text { - hoge algemene waardering } \\
\text { - hoge score } \\
\text { computervaardigheden }\end{array}$ \\
\hline $\begin{array}{l}\text { Overig (speciale taken en } \\
\text { hulp bij leidinggeven) }\end{array}$ & $\begin{array}{l}\text { - hoge score vakkennis } \\
\text { - hoge score rekenen } \\
\text { - hoger opgeleiden } \\
\text { - ouderen }\end{array}$ & $\begin{array}{l}\text { - hoge algemene waardering } \\
\text { - hoge score adviseren }\end{array}$ \\
\hline
\end{tabular}


Om een beeld te krijgen van de competenties waarover dossiermedewerkers beschikken is hen gevraagd een oordeel te geven over hun capaciteiten met betrekking tot de activiteiten die ze verrichten. Tabel 4.7 geeft aan welk punt de dossiermedewerkers zichzelf gemiddeld geven voor hun werkzaamheden. De waardering heeft plaatsgevonden op een vijfpuntsschaal. De verschillen in gemiddelde beoordeling zijn niet groot. Het beste cijfer wordt gemiddeld gegeven voor toekennen en verificatie; het slechtste cijfer voor beheerswerkzaamheden en inlichten. Dossiermedewerkers van Leven waarderen zichzelf doorgaans hoger dan dossiermedewerkers van Risico. Dit verschil wordt met name veroorzaakt door het feit dat medewerkers die al langer bij Het Kantoor werken zichzelf relatief hoog inschatten. Voor medewerkers van Leven is dit het geval. In een aantal gevallen blijkt met name de tijd in de huidige functie een rol te spelen, terwijl in andere gevallen de totale diensttijd bij Het Kantoor bepalend blijkt te zijn.

Alleen met betrekking tot de begeleiding van medewerkers is de score voor Risico hoger. Eerder was al aan de orde gekomen dat de begeleiding van medewerkers bij Risico in handen is van een kleinere groep medewerkers.

Tabel 4.7

Gemiddeld cijfer (vijfpuntsschaal) dat medewerkers zichzelf toekennen voor de werkzaamheden die ze genoemd hebben

\begin{tabular}{lccc}
\hline Werkzaamheid & Leven & Risico & Totaal \\
\hline Toekennen & 4,4 & 4,1 & 4,3 \\
Beheerswerkzaamheden & 4,0 & 3,7 & 3,8 \\
Corresponderen & 4,0 & 4,0 & 4,0 \\
Inlichten & 3,9 & 3,7 & 3,8 \\
Begeleiden medewerkers & 3,8 & 4,0 & 3,9 \\
Verificatie & 4,3 & 4,0 & 4,3 \\
& & & \\
\hline
\end{tabular}

Omdat hier alleen beoordelingen in aanmerking zijn genomen van dossiermedewerkers die ook daadwerkelijk de betreffende werkzaamheid hebben genoemd, scoren deze 'specialisten' van Risico hoger dan de begeleiders van Leven.

Het ligt voor de hand dat de inschattingen van dossiermedewerkers bij Het Kantoor over hun kwaliteiten met betrekking tot de werkzaamheden die men verricht sterk samenhangen met de waarderingen die men heeft gegeven voor de verschillende aspecten van het werk. Tabel 4.8 laat daarom de belangrijkste positieve samenhangen zien. De inschattingen van de eigen kwaliteiten bij toekennen blijken vooral samen te hangen met de gepercipieerde nauwkeurigheid. De eigen beoordeling van berekenen blijkt daarentegen meer samen te hangen met vakkennis. 
Tabel 4.8

Relatie tussen inschatting eigen kwaliteiten voor werkzaamheden en diverse aspecten van het werk (extra eigen beoordeling per punt extra waardering voor de genoemde aspecten)

\begin{tabular}{lll}
\hline Werkzaamheid & $\begin{array}{l}\text { Competentie hangt } \\
\text { samen met }\end{array}$ & Mate van samenhang \\
\hline Toekennen & $\begin{array}{l}\text { nauwkeurigheid } \\
\text { plannen }\end{array}$ & 0,56 \\
& computervaardigheid & 0,30 \\
& vakkennis & 0,19 \\
Berekenen & nauwkeurigheid & 0,36 \\
Beheerswerkzaamheden & adviseren & 0,15 \\
Corresponderen & schrijven & 0,28 \\
& fouten uitzoeken & 2,03 \\
& nauwkeurigheid & 0,59 \\
Inlichten & adviseren & \\
& vakkennis & 0,42 \\
Begeleiden medewerkers & fouten constateren & 0,29 \\
& instrueren & 1,34 \\
Verificatie & fouten uitwerken & 0,13 \\
& wiskunde & 1,82 \\
vakkennis & 0,55 \\
Overig & plannen & 0,32 \\
& geen relatie & 0,29 \\
\hline
\end{tabular}




\section{Kwalificatieproblemen en hun oorzaken}

\subsection{Inleiding}

Voor een goed draaiende organisatie is het nodig dat de medewerkers over de kennis en vaardigheden beschikken die nodig zijn om hun functie naar behoren uit te oefenen. leder werk heeft uiteraard zijn eigen specifieke elementen en routines. Het zal daarom altijd een tijd duren voordat een nieuwe medewerker die binnenkomt bij Het Kantoor het werk goed beheerst. Zoals in het eerste hoofdstuk al is opgemerkt, is de inhoud van het werk echter geen constante factor. Meer en meer lijkt de werkinhoud aan voortdurende veranderingen onderhevig te zijn. Het aanpassingsproces van de dossiermedewerkers betreft dus niet alleen de inwerktijd die nodig is nadat men de organisatie is binnengekomen. ledere keer weer opnieuw moeten de dossiermedewerkers van Het Kantoor zich aanpassen aan organisatieveranderingen, nieuwe ontwikkelingen op het gebied van computers en veranderende regelgeving.

In dit hoofdstuk wordt daarom ingegaan op de wijze waarop dossiermedewerkers zich aanpassen aan de behoeftes van de organisatie. Allereerst wordt ingegaan op de inwerktijd en vervolgens worden de belangrijke veranderingen bij Het Kantoor van de afgelopen tijd en de nabije toekomst onder de loep genomen.

\subsection{Inwerktijd}

In tabel 5.1 wordt bekeken hoe lang dossiermedewerkers nodig denken te hebben voordat ze het huidige werk onder de knie te hebben. Zeer opmerkelijk is dat vrouwen een veel kortere inwerkperiode opgeven dan mannen. Waar mannen gemiddeld 19 maanden nodig hebben, volstaat in de ogen van vrouwen een periode van 9 maanden. Dit verschil manifesteert zich op alle opleidingsniveaus.

Tabel 5.1

Aantal maanden dat nodig is om het werk onder de knie te krijgen

\begin{tabular}{lccc}
\hline Opleidingsniveau & Man & Vrouw & Totaal \\
\hline Geen of VBO & 11 & 8 & 11 \\
MAVO/MULO & 17 & 3 & 15 \\
HAVO/NWO & 36 & 17 & 29 \\
MBO & 15 & 8 & 12 \\
HBO/WO & 15 & 5 & 10 \\
Totaal & 19 & 9 & 15 \\
\hline
\end{tabular}

De langste inwerktijd wordt opgegeven door dossiermedewerkers met een HAVO- of VWO-diploma. Zowel lager als hoger opgeleiden denken sneller ingewerkt te zijn. Met name mensen in de leeftijdsgroep van 36 tot 45 jaar denken dat een lange inwerkperiode nodig is. Dit blijkt overigens niet samen te hangen met de lengte van 
de diensttijd bij Het Kantoor. Bij Leven wordt gemiddeld een periode van 18 maanden genoemd, terwijl bij Risico dit gemiddelde op 13 maanden ligt. Enkele teams bij zowel Leven als Risico springen er uit qua gemiddelde inwerkperiode. Daarnaast blijken dossiermedewerkers die opvallend veel verschillende werkzaamheden opgeven, ook een lange inwerktijd nodig te vinden.

De verschillen in inwerktijd kunnen er op duiden dat mensen met een bepaalde achtergrond zich sneller de vereisten voor het werk eigen maken dan anderen. Dit zou implicaties kunnen hebben voor het selectiebeleid, maar betekent wellicht ook dat de wijze waarop de inwerkperiode door het bedrijf wordt ondersteund middels training en coaching van persoon tot persoon zou moeten verschillen.

Uit een verdere analyse van de inwerktijd blijkt dat de competenties waarover de dossiermedewerkers in hun eigen ogen of volgens hun managers beschikken nauwelijks van invloed zijn op de benodigde inwerktijd. Ook de werkzaamheden die men opgeeft blijken geen verband met de inwerktijd te hebben. Inwerktijd lijkt daarmee vooral bepaald te worden door bedrijfsspecifieke factoren die voor iedereen van toepassing zijn.

\subsection{Veranderingen in het werk}

Naast de inwerktijd die nieuwe medewerkers nodig hebben om thuis te raken in de werkzaamheden van Het Kantoor, is er de laatste jaren voortdurend sprake van veranderingen waardoor de dossiermedewerkers zich moeten blijven ontwikkelen om mee te kunnen met het werk. Tabel 5.2 brengt dit in beeld. De meeste dossiermedewerkers bij Het Kantoor blijken inderdaad van mening te zijn dat het werk de laatste tijd aanzienlijk is veranderd. De medewerkers verwachten ook dat er de komende jaren nog veel zal veranderen. In tabel 5.3 worden de belangrijkste veranderingen die medewerkers hebben ervaren op een rij gezet. De drie meest genoemde veranderingen zijn: regelgeving, automatisering en organisatorische veranderingen.

Tabel 5.2

Percentage medewerkers dat van oordeel is dat het werk is veranderd en dat denkt dat het werk de komende jaren zal veranderen

\begin{tabular}{lcc}
\hline & $\begin{array}{c}\text { Verleden } \\
\%\end{array}$ & $\begin{array}{c}\text { Toekomst } \\
\%\end{array}$ \\
\hline Ja & 75 & 79 \\
Nee & 15 & 14 \\
Ik werk hier nog maar kort/weet niet & 10 & 7 \\
Totaal & 100 & 100 \\
\hline
\end{tabular}

Organisatorische veranderingen kunnen zowel betrekking hebben op veranderingen in het management of de organisatiestructuur als op een verandering in de rol van de medewerker binnen de organisatie. 
Tabel 5.3

De meest genoemde veranderingen (percentage van de genoemde veranderingen. Omdat meerdere antwoorden mogelijk zijn, heeft dus meer dan $34 \%$ van de medewerkers bijvoorbeeld regelgeving genoemd)

\begin{tabular}{lr}
\hline Verandering & $\%$ \\
\hline Regelgeving & 34 \\
Automatisering & 30 \\
Organisatorische veranderingen & 23 \\
Werkdruk & 5 \\
Klantgerichter werken & 4 \\
Specialisatie & 2 \\
Overige & 2 \\
Totaal & 100 \\
\hline
\end{tabular}

De betekenis van deze veranderingen voor eventuele competentieproblemen komt natuurlijk pas naar voren als medewerkers ook moeite hebben om zich aan te passen aan de veranderingen. Uit tabel 5.4 blijkt dat organisatorische veranderingen in dat opzicht als het meest problematisch worden ervaren. Ongeveer $50 \%$ van de medewerkers die veranderende regelgeving noemen, blijkt vrijwel geen problemen met deze veranderingen te hebben gehad. De andere helft van de medewerkers had meestal slechts enige problemen hiermee.

Tabel 5.4

Moeite die medewerkers hadden met de drie meest voorkomende veranderingen, voor zover ze deze verandering noemden.

\begin{tabular}{lccc}
\hline & Regelgeving & Automatisering & $\begin{array}{c}\text { Organisatorische } \\
\text { veranderingen } \\
\%\end{array}$ \\
\hline Zeer veel & $\%$ & $\%$ & 0 \\
Veel & 3 & 0 & 25 \\
Enige & 0 & 24 & 44 \\
Vrijwel geen & 47 & 28 & 31 \\
Geen & 50 & 0 & 0 \\
Totaal & 0 & 100 & 100 \\
\hline
\end{tabular}

Ook bij automatisering heeft ongeveer de helft van de dossiermedewerkers die deze verandering noemden geen moeite met de verandering gehad, maar voor de andere helft die wel aangaf moeite te hebben gehad waren de problemen groter dan bij de veranderende regelgeving. Een HRM-functionaris duidt aan dat "er een generatie mensen werkzaam is binnen Het Kantoor, die moeite heeft met de ontwikkelingen op het gebied van computers. 'Knoppenangst' is ook binnen Het Kantoor niet vreemd. De begeleiding op dit gebied valt met name onder de noemer training on the job. Medewerkers leren omgaan met systemen door ermee te werken en door de mogelijkheid te krijgen te allen tijde vragen te stellen aan deskundigen". In het geval van organisatorische veranderingen heeft slechts $30 \%$ vrijwel geen moeite om zich aan te passen. 
De moeite die de medewerkers hebben met veranderingen blijkt aanzienlijk te verschillen tussen de twee bedrijfsonderdelen. Tabel 5.5 laat zien dat bij Leven vooral de veranderende regelgeving voor veel problemen zorgde, terwijl bij Risico organisatorische veranderingen voor de meeste problemen zorgden. Bij automatisering is er weinig verschil tussen de twee bedrijfsonderdelen. Overigens komt het percentage medewerkers met problemen bij de aanpassing nooit boven de $25 \%$.

Doordat niet iedereen alle veranderingen heeft genoemd zijn de percentages medewerkers die een verandering daadwerkelijk noemden en ook aangaven hier moeite mee te hebben lager. Tabel 5.5 geeft aan dat het hierbij per verandering hoogstens om zo'n $15 \%$ van de medewerkers gaat. Sommige medewerkers hebben moeite met meerdere veranderingen. In totaal blijkt royaal 1 op de 3 medewerkers moeite te hebben gehad met een bepaalde verandering. Gezien de omvang van het veranderingsproces bij Het Kantoor lijkt dit geen hoog percentage.

Tabel 5.5

Percentage medewerkers met minstens enige moeite met de aanpassing aan een verandering bij Leven en Risico

\begin{tabular}{lccc}
\hline & $\begin{array}{c}\text { Regelgeving } \\
\%\end{array}$ & $\begin{array}{c}\text { Automatisering } \\
\%\end{array}$ & $\begin{array}{c}\text { Organisatorische } \\
\text { veranderingen } \\
\%\end{array}$ \\
\hline Leven & 22 & 12 & 6 \\
Risico & 8 & 14 & 16 \\
Totaal & 15 & 13 & 11 \\
\hline
\end{tabular}

Tabel 5.6

Percentage medewerkers met minstens enige moeite met de aanpassing aan een verandering per opleidingsniveau

\begin{tabular}{lccc}
\hline Opleidingsniveau & Regelgeving & Automatisering & $\begin{array}{c}\text { Organisatorische } \\
\text { veranderingen } \\
\%\end{array}$ \\
\hline Geen of VBO & $\%$ & $\%$ & 11 \\
MAVO/MULO & 22 & 22 & 12 \\
HAVONWO & 28 & 16 & 16 \\
MBO & 5 & 26 & 9 \\
HBOMO & 15 & 3 & 8 \\
Totaal & - & 8 & 11 \\
\hline
\end{tabular}

Tabel 5.6 laat zien dat met name de lager opgeleiden moeite hebben met het aanpassingsproces, hoewel ongediplomeerden en VBO'ers opvallend weinig problemen zeggen te hebben gehad. Het zou kunnen zijn dat deze groep medewerkers door hun taken binnen de organisatie niet zo sterk met de betreffende veranderingen zijn geconfronteerd. 
Ook lopen de problemen die de medewerkers ervaren bij de drie meest genoemde veranderingen sterk uiteen, zoals tabel 5.7 laat zien. Bij de veranderende regelgeving wordt in de helft van de gevallen gewezen op vakinhoudelijke problemen.

Bij automatisering wordt naast de vakinhoudelijke aspecten ook gewezen op tekortkomingen van het computersysteem. Bij de organisatorische veranderingen hebben gebrekkige communicatie, tijdgebrek en te weinig begeleiding een belemmerende invloed. Bij alle drie de veranderingen wordt de omschakeling als een belangrijk knelpunt gezien.

Tabel 5.7

Belangrijkste problemen bij de drie meest voorkomende veranderingen

\begin{tabular}{lccc}
\hline & $\begin{array}{c}\text { Regelgeving } \\
\text { Aard van probleem }\end{array}$ & $\begin{array}{c}\text { Automatisering } \\
\text { Organisatorische } \\
\text { veranderingen } \\
\%\end{array}$ & $\begin{array}{c}\text { \% } \\
\text { Communicatie }\end{array}$ \\
Vakinhoudelijk & 7 & - & 19 \\
Computersysteem & 47 & 32 & 13 \\
Tijdgebrek & 10 & 32 & - \\
Te weinig begeleiding & 7 & - & 9 \\
Omschakeling & 7 & 20 & 6 \\
Overige & 17 & 8 & 100 \\
Totaal & 7 & 100 & 6 \\
\hline
\end{tabular}

Tabel 5.8 geeft een beeld van het soort veranderingen dat genoemd wordt bij Leven en Risico. Hoewel Leven-medewerkers vaker moeite hadden met veranderende regelgeving, blijkt deze verandering vaker genoemd te worden door Risicomedewerkers. Kennelijk is voor veel dossiermedewerkers van Risico deze verandering geen probleem. Organisatorische veranderingen worden bij Risico vaker genoemd dan bij Leven. Ten slotte wordt bij Leven in $11 \%$ van de gevallen genoemd dat men klantgerichter is moeten gaan werken. Bij Risico wordt deze verandering niet genoemd. Tussen mannen en vrouwen blijken er weinig verschillen te zijn in de veranderingen die men noemt. Vrouwen noemen vaker dan mannen de toenemende werkdruk en de toenemende klantgerichtheid. Ook automatisering wordt door vrouwen veel vaker dan door mannen genoemd (37\% versus $20 \%$ ).

Tabel 5.8

De meest genoemde veranderingen bij Leven versus Risico

\begin{tabular}{lrrr}
\hline Verandering & Leven & Risico & Totaal \\
\hline Specialisatie & 3 & - & 1 \\
Regelgeving & 11 & 22 & 17 \\
Automatisering & 31 & 27 & 29 \\
Organisatorische veranderingen & 31 & 37 & 54 \\
Klantgerichter & 11 & 10 & 9 \\
Werkdruk & 9 & 5 & 4 \\
Overig & 3 & 100 & 100 \\
Totaal & 100 & & \\
\hline
\end{tabular}


Naar leeftijd zijn er wel aanzienlijke verschillen in de veranderingen die worden genoemd, zoals tabel 5.9 laat zien. Jongeren tot en met 35 wijzen relatief vaak op regelgeving, maar vooral op organisatorische veranderingen. Medewerkers boven de 46 noemen opmerkelijk vaak de automatisering en ook de werkdruk als belangrijke verandering.

Tabel 5.9

De meest genoemde veranderingen per leeftijdscategorie

\begin{tabular}{lrrr}
\hline Verandering & -35 & $36-45$ & $46+$ \\
\hline Specialisatie & -5 & 4 & - \\
Regelgeving & 19 & 21 & 10 \\
Automatisering & 19 & 29 & 45 \\
Organisatorische veranderingen & 44 & 33 & 20 \\
Klantgerichter & 6 & 8 & - \\
Werkdruk & 9 & 4 & 15 \\
Overig & 3 & - & 10 \\
Totaal & 100 & 100 & 100 \\
\hline
\end{tabular}

Veranderende regelgeving wordt vooral genoemd door mensen die een slechte algemene beoordeling van hun manager krijgen en die juist goed zijn in instrueren en rekenen. Paradoxaal genoeg blijken binnen deze groep juist weer degenen met een goede algemene beoordeling die slecht zijn in rekenen aan te geven dat ze veel moeite met de betreffende verandering hebben. Dossiermedewerkers die door hun afdelingshoofd hoog worden ingeschat op het geven van adviezen en vakkennis blijken minder vaak de automatisering als verandering op te geven. Degenen die goed zijn in planning noemen deze verandering juist wel vaak. Opnieuw blijkt dat binnen de groep die automatisering noemt als een belangrijke verandering, de dossiermedewerkers die een hoge algemene waardering krijgen aan te geven dat ze relatief veel moeite hadden met de aanpassingen. Het lijkt er op dat juist de medewerkers met een hogere algemene beoordeling van de manager zich bewuster zijn van hun eigen sterke en zwakke punten en daardoor eerder aangegeven problemen met bepaalde veranderingen te hebben gehad.

Zij die goed zijn in instrueren en rekenen hadden juist minder moeite met de automatisering. Computervaardigheden blijken geen invloed hierop te hebben. De vraag of medewerkers aangeven dat ze te maken hebben gehad met organisatorische veranderingen, blijkt nauwelijks samen te hangen met de competenties waarover mensen beschikken. Hoger opgeleiden en jongeren blijken veel vaker de organisatorische veranderingen te noemen, maar hebben voor zover zij dit noemen, juist minder problemen met deze veranderingen. Het zou kunnen dat de jonge en hoogopgeleide werknemers, doordat ze waarschijnlijk nog geen of slechts enkele veranderingen in het werk hebben meegemaakt in het verleden, veranderingen meer als een schok ervaren dan oudere werknemers, die gewend zijn aan veranderingen. Het vermogen om zich snel aan te passen aan de veranderingen is echter bij de laatstgenoemde groep kleiner. 


\section{Consequenties voor de arbeidsmarktpositie}

\subsection{Inleiding}

Tekortschietende competenties en problemen bij het uitoefenen van het werk hoeven nog niet onmiddellijk te betekenen dat de positie van de betrokkene binnen het bedrijf in gevaar komt. Veel medewerkers hebben immers een vaste aanstelling bij Het Kantoor waardoor hun positie in het geval van kwalificatieveroudering niet meteen bedreigd wordt. Zelfs al zou er sprake zijn van het ontslag van een groep medewerkers dan nog zullen in het algemeen niet de kennis en vaardigheden waarover men beschikt bepalend zijn voor de vraag wie zal moeten gaan en wie zal kunnen blijven. Vanuit het bedrijf gezien zijn er daarom andere instrumenten nodig om mensen zoveel mogelijk te stimuleren mee te gaan met de nieuwe eisen die het werk stelt. Een HRM-functionaris geeft aan dat dit niet altijd makkelijk is: "Aan de oppervlakte lijkt alles wel vaak goed te zitten, maar de praktijk leert dat er vaak qua personeelsbeleid grote lacunes zijn. Er zijn in iedere organisatie minder presterende mensen. Bij Het Kantoor lijken deze mensen er niet te zijn, maar dit komt doordat de beoordelingsrange naar boven is verschoven, wat inhoudt dat normaal functionerende mensen worden te hoog beoordeeld en dat minder presterende mensen nog net 'normaal' functioneren."

\subsection{Kans op nieuw werk en risico op werkloosheid}

Om een beeld te krijgen van de positie van de dossiermedewerkers in het bedrijf is het daarom interessant om in te gaan op de vraag of de betreffende medewerkers zelf denken moeite te hebben om elders een vergelijkbare baan te vinden. Tabel 6.1 laat zien dat met name ouderen denken dat het moeilijk zal zijn een vergelijkbare baan te vinden. Ook is er, zoals verwacht kan worden, een duidelijk verband tussen opleidingsniveau en de mogelijkheden die men ziet om vergelijkbaar werk te vinden. Dit valt te zien in tabel 6.2. Onder de hoger opgeleiden is slechts $16 \%$ van mening dat dit veel of zeer veel moeite zal kosten. VBO'ers zijn vergeleken met Mavisten opvallend optimistisch over hun mogelijkheden op de arbeidsmarkt.

Tabel 6.1

Moeite met vinden van vergelijkbaar werk per leeftijdscategorie

\begin{tabular}{lrrrr}
\hline & -35 & $36-45$ & $46+$ & Totaal \\
\hline Zeer veel & 5 & 23 & 58 & 25 \\
Veel & 25 & 49 & 31 & 35 \\
Enige & 42 & 20 & - & 23 \\
Vrijwel geen & 24 & - & 8 & 11 \\
Geen enkele & 3 & 6 & 4 & 4 \\
Totaal & 100 & 100 & 100 & 100 \\
\hline
\end{tabular}


Tabel 6.2

Moeite met vinden van vergelijkbaar werk naar opleidingsachtergrond

\begin{tabular}{lrrrrr}
\hline & VBO & MAVO & HAVO/NWO & MBO & HBONO \\
\hline Zeer veel & 22 & 52 & 26 & 12 & 8 \\
Veel & 56 & 28 & 37 & 46 & 8 \\
Enige & 11 & 4 & 32 & 27 & 46 \\
Vrijwel geen & 11 & 4 & - & 15 & 31 \\
Geen enkele & - & 12 & - & - & 8 \\
Totaal & 100 & 100 & 100 & 100 & 100 \\
\hline
\end{tabular}

Tabel 6.3 laat zien dat dossiermedewerkers van Leven veel meer moeite denken te hebben met het vinden van vergelijkbaar werk dan hun Risico-collega's. De hogere leeftijd van Leven-medewerkers is hier de voornaamste oorzaak van.

Tabel 6.3

Moeite met vinden van vergelijkbaar werk naar bedrijfsonderdeel

\begin{tabular}{lcc}
\hline & $\begin{array}{c}\text { Leven } \\
\%\end{array}$ & $\begin{array}{c}\text { Risico } \\
\%\end{array}$ \\
\hline Zeer veel & 35 & 16 \\
Veel & 39 & 32 \\
Enige & 16 & 30 \\
Vrijwel geen & 36 & 14 \\
Geen enkele & - & 8 \\
Totaal & 100 & 100 \\
\hline
\end{tabular}

Zoals is opgemerkt hoeft het met moeite vinden van nieuw werk nog niet te betekenen dat men ook een grotere kans heeft de huidige baan te verliezen. In tabel 6.4 wordt bekeken welk deel van de medewerkers de kans op het verlies van zijn baan bij Leven of Risico minstens fifty-fifty acht. Personen met een HAVONWO, $\mathrm{MBO}, \mathrm{HBO}$ of WO opleiding blijken aanzienlijk minder zeker van hun werk te zijn dan de VBO'ers en Mavisten. Ook los van het feit dat hoger opgeleiden de organisatie pas later zijn binnengekomen blijken zij minder zeker van hun werk te zijn.

Tabel 6.4

Percentage medewerkers dat denkt dat de kans om de baan kwijt te raken minstens $50-50$ is, per opleidingsniveau

\begin{tabular}{lc}
\hline Opleidingsniveau & $\%$ \\
\hline VBO & 11 \\
MAVO & 12 \\
HAVONWO & 32 \\
MBO & 27 \\
HBONWO & 31 \\
Totaal & 17 \\
\hline
\end{tabular}


Tabel 6.5 laat zien dat de dossiermedewerkers van Risico de kans om hun baan te verliezen aanzienlijk hoger inschatten dan Leven'ers. Degenen die deze kans zeer groot achten zijn allemaal jongeren. Vrouwen zijn gemiddeld zekerder van hun positie.

Tabel 6.5

Ingeschatte kans om baan te verliezen per bedrijfsonderdeel

\begin{tabular}{lrrr}
\hline & Leven & Risico & Totaal \\
\hline Zeker & - & - & - \\
Zeer waarschijnlijk & 2 & 10 & 6 \\
Fifty-fifty & 12 & 22 & 17 \\
Redelijk onwaarschijnlijk & 18 & 16 & 4 \\
Erg onwaarschijnlijk & 8 & - & 51 \\
Geen kans & 55 & 46 & 5 \\
Weet niet & 4 & 6 & 100 \\
Totaal & 100 & 100 & \\
\hline
\end{tabular}

Hoewel het dus vaak om hoger opgeleide jongeren gaat, blijken degenen die een hogere kans denken te hebben om hun baan kwijt te raken toch ook meer dan gemiddeld problemen te verwachten bij het vinden van werk. Tabel 6.6 laat zien dat $70 \%$ van dossiermedewerkers die de kans groot acht de baan te verliezen, ook problemen voorziet met het vinden van een nieuwe baan. Onder degenen die niet denken hun baan te verliezen is dit percentage $58 \%$.

Tabel 6.6

De moeite om een nieuwe vergelijkbare baan te vinden, afhankelijk van de ingeschatte kans de huidige baan kwijt te raken

\begin{tabular}{lcc}
\hline $\begin{array}{l}\text { Ingeschatte kans op verlies van baan }> \\
\text { moeite met vinden van baan }\end{array}$ & $\begin{array}{c}\text { Groot } \\
\%\end{array}$ & $\begin{array}{c}\text { Klein } \\
\%\end{array}$ \\
\hline $\mathrm{Ja}$ & 70 & 58 \\
$\mathrm{Nee}$ & 30 & 42 \\
Totaal & 100 & 100 \\
\hline
\end{tabular}

Het ligt natuurlijk voor de hand om te veronderstellen dat dossiermedewerkers die moeite hebben met veranderingen bij Het Kantoor, ook minder makkelijk een baan elders denken te kunnen krijgen. Uit tabel 6.7 blijkt echter dat dit niet altijd het geval hoeft te zijn. Degenen die moeite hebben met de veranderende regelgeving of automatisering, denken duidelijk meer moeite te hebben om vergelijkbaar werk buiten Het Kantoor te vinden dan anderen. Voor organisatorische veranderingen ligt dit echter omgekeerd. Kennelijk hebben juist degenen die flexibel denken te zijn op de externe arbeidsmarkt, relatief veel problemen met interne organisatieveranderingen. Tabel 6.8 laat dezelfde verschillen per bedrijfsonderdeel zien. 
Tabel 6.7

Ingeschatte moeite met vinden werk, afhankelijk van de vraag of de dossiermedewerker problemen heeft met een drietal veranderingen

\begin{tabular}{lcc}
\hline $\begin{array}{l}\text { Problemen met verandering }> \\
\text { Verandering }\end{array}$ & Ja & Nee \\
& \% Moeite met werk vinden & \% Moeite met werk vinden \\
Regelgeving & 93 & 55 \\
Automatisering & 77 & 58 \\
Organisatorisch & 55 & 61 \\
\hline
\end{tabular}

Tabel 6.8

Ingeschatte moeite met vinden werk, afhankelijk van de vraag of de dossiermedewerker problemen heeft met een drietal veranderingen per bedrijfsonderdeel

\begin{tabular}{ll}
\hline $\begin{array}{l}\text { Problemen met verandering }> \\
\text { Verandering }\end{array}$ & $\begin{array}{c}\text { Ja } \\
\% \text { Moeite met werk vinden }\end{array}$ \\
\hline
\end{tabular}

Leven

Regelgeving

Automatisering

Organisatorisch

Risico

Regelgeving

Automatisering

Organisatorisch

$\begin{array}{ll}91 & 68 \\ 83 & 72 \\ 67 & 74\end{array}$

In tabel 6.9 wordt gekeken naar de relatie tussen de problemen die dossiermedewerkers hebben met veranderingen en de kans die zij denken te hebben hun baan te verliezen. Het blijkt dat medewerkers die moeite hebben met veranderingen inderdaad ook meer kans denken te hebben hun baan kwijt te raken. Met name bij organisatorische veranderingen is dit verschil aanzienlijk. Een dergelijk patroon is bij beide bedrijfsonderdelen waarneembaar. Bij Risico is echter over het algemeen de angst om de baan kwijt te raken groter dan bij Leven.

Tabel 6.9

Ingeschatte moeite met vinden werk, afhankelijk van de vraag of men problemen heeft met een drietal veranderingen

\begin{tabular}{lcc}
\hline $\begin{array}{l}\text { Problemen met verandering }> \\
\text { Verandering }\end{array}$ & $\begin{array}{c}\text { Ja } \\
\text { \% Kans baan kwijt te raken }\end{array}$ & $\begin{array}{c}\text { Nee } \\
\% \text { Kans baan kwijt te raken }\end{array}$ \\
\hline Regelgeving & 33 & 21 \\
Automatisering & 31 & 22 \\
Organisatorisch & 46 & 21
\end{tabular}

In de tabellen 6.10 en 6.11 wordt ingegaan op de redenen om optimistisch of pessimistisch te zijn over de mogelijkheden om de baan te behouden. Zowel bij Leven als bij Risico is vertrouwen in het bedrijf de belangrijkste reden om niet bang 
te zijn de baan te verliezen. Ook vertrouwen in eigen kunnen blijkt een belangrijke factor te zijn. Laag opgeleiden vertrouwen over het algemeen meer op de organisatie. Vrouwen vertrouwen daarentegen meer dan mannen op hun eigen kunnen.

Bij Leven speelt een gebrek aan vertrouwen in de organisatie sterker dan bij Risico als argument om niet in het behoud van de baan te geloven. Hierbij dient men wel te bedenken dat de groep dossiermedewerkers die bang is de baan te verliezen bij Leven veel kleiner is dan bij Risico. Als aandeel van alle medewerkers is de groep zonder vertrouwen in de organisatie bij Leven daarom kleiner dan bij Risico. Bij Risico blijken tijdelijke contracten en een gebrek aan vertrouwen in eigen kunnen ook nog belangrijke redenen te zijn om aan het behoud van de baan te twijfelen.

Tabel 6.10

Redenen om positief te zijn over kans om baan te behouden

\begin{tabular}{lrrr}
\hline & $\begin{array}{c}\text { Leven } \\
\%\end{array}$ & $\begin{array}{c}\text { Risico } \\
\%\end{array}$ & $\begin{array}{c}\text { Totaal } \\
\%\end{array}$ \\
\hline Vertrouwen in Het Kantoor & 43 & 50 & 46 \\
Vertrouwen in eigen kunnen & 28 & 25 & 26 \\
Vast contract & 3 & 3 & 3 \\
Externe factoren & -5 & 3 & 1 \\
Overige & 18 & 9 & 14 \\
Totaal & 100 & 100 & 100 \\
\hline
\end{tabular}

Tabel 6.11

Redenen om negatief te zijn over kans om baan te behouden

\begin{tabular}{lrrr}
\hline & $\begin{array}{c}\text { Leven } \\
\%\end{array}$ & $\begin{array}{c}\text { Risico } \\
\%\end{array}$ & $\begin{array}{c}\text { Totaal } \\
\%\end{array}$ \\
\hline $\begin{array}{l}\text { Geen vertrouwen in Het Kantoor } \\
\text { Geen vertrouwen in eigen kunnen }\end{array}$ & 71 & 50 & 57 \\
$\begin{array}{l}\text { Tijdelijk contract } \\
\text { Externe factoren }\end{array}$ & - & 6 & 4 \\
Overige & 29 & 13 & 9 \\
Totaal & - & 6 & 22 \\
& 100 & 100 & 4 \\
\hline
\end{tabular}

In tabel 6.12 wordt een vergelijking gemaakt tussen de beoordeling van de managers van dossiermedewerkers die denken makkelijk een vergelijkbare baan te kunnen vinden en degenen die hier moeite mee denken te hebben. Degenen die meer moeite met het vinden van ander werk denken te hebben, scoren op alle genoemde aspecten lager dan degenen die hiermee geen moeite denken te hebben. Voor een groot deel hangen deze beoordelingen echter onderling samen en houden ze ook verband met andere achtergrondkenmerken van de betrokkenen. Uit een simultane analyse blijkt dat met name ouderen en degenen die al lange tijd bij Het Kantoor werken veel moeite op de externe arbeidsmarkt denken te hebben. 
Daarnaast geldt dit met name voor ongediplomeerden, VBO'ers en mensen met een MBO-opleiding. Juist degenen die - gezien deze achtergrondkenmerken - een hoge algemene waardering van hun manager krijgen en degenen die een hoog punt krijgen voor schrijven, hebben volgens hun eigen inschatting de grootste moeite om een nieuwe baan te krijgen. Adviseren, computervaardigheden en rekenen zijn competenties die ingeschatte kansen op de externe arbeidsmarkt juist vergroten.

Tabel 6.12

Beoordeling door managers van de dossiermedewerkers die al dan niet moeite denken te hebben met het vinden van een vergelijkbare baan, in het algemeen en op een zevental facetten (tienpuntsschaal)

\begin{tabular}{lcc}
\hline & Geen moeite & Moeite \\
\hline Algemeen & 7,5 & 7,3 \\
Instrueren & 7,7 & 6,5 \\
Adviezen klanten & 7,8 & 7,3 \\
Vakkennis & 7,6 & 7,3 \\
Computervaardigheden & 7,7 & 7,2 \\
Planning & 7,4 & 7,1 \\
Schrijven & 6,9 & 6,7 \\
Rekenen & 7,9 & 7,6 \\
\hline
\end{tabular}

In tabel 6.13 wordt een vergelijkbare opsplitsing gemaakt tussen degenen die een grote kans denken te hebben hun baan te verliezen en degenen die denken dat deze kans klein is. Dossiermedewerkers die inschatten een hoge kans te hebben op verlies van werk blijken niet altijd lager te scoren. Op een aantal facetten scoren zij zelfs aanzienlijk beter dan hun collega's die zekerder zijn van hun baan. Kennelijk is er weinig samenhang tussen iemands capaciteiten en de mogelijkheden die men denkt te hebben om bij Het Kantoor te blijven. Uit een simultane analyse blijkt van de beoordelingen door het afdelingshoofd alleen vakkennis een positieve invloed te hebben op de kans de baan te verliezen. Daarnaast zien vooral de hoger opgeleiden een risico op verlies van werk.

Tabel 6.13

Beoordeling door managers van de dossiermedewerkers die al dan niet een grote kans denken te hebben om hun baan te verliezen, in het algemeen en op een zevental facetten (tienpuntsschaal)

\begin{tabular}{lcc}
\hline & Weinig kans op baanverlies & Grote kans op baanverlies \\
\hline Algemeen & 7,4 & 7,4 \\
Instrueren & 6,8 & 7,5 \\
Adviezen klanten & 7,5 & 7,5 \\
Vakkennis & 7,4 & 7,5 \\
Computervaardigheden & 7,4 & 7,5 \\
Planning & 7,3 & 7,2 \\
Schrijven & 6,8 & 6,8 \\
Rekenen & 7,7 & 7,8 \\
\hline
\end{tabular}

Door een combinatie van beide analyses kan bekeken worden welke groepen bij Het Kantoor zowel bang zijn om hun baan te verliezen als ook moeite denken te hebben 
met het vinden van nieuw werk. Er blijkt dan nauwelijks nog een verband te worden gevonden. Voor ouderen en degenen die reeds lang bij Het Kantoor werken is de situatie iets minder gunstig, maar dit effect is niet substantieel. Eigenlijk denken, alleen degenen met een hoge inschatting van hun vakkennis door de manager, een zwakke positie in te nemen omdat zij zowel een hogere kans denken te hebben hun baan te verliezen, maar ook meer moeite denken te hebben nieuw werk te kunnen krijgen. 


\section{Wat kan er worden gedaan?}

\subsection{Inleiding}

Uit het vorige hoofdstuk is gebleken dat competentieproblemen nauwelijks samenhangen met de risico's die medewerkers denken te lopen hun baan te verliezen. Als dit gebeurt zijn echter wel hun gepercipieerde mogelijkheden op de externe arbeidsmarkt afhankelijk van zowel hun leeftijd als bepaalde competenties. Binnen Het Kantoor is het uiteraard ook van belang om te bekijken wat er gedaan kan worden om kennisveroudering tegen te gaan en er voor te zorgen dat de competenties van de medewerkers op peil komen en blijven.

In dit hoofdstuk zal daarom worden ingegaan op de manier waarop de organisatie en de betrokken dossiermedewerkers omgaan met de veranderingen die zij hebben doorgemaakt. Allereerst zal hierbij in paragraaf 7.2 worden bekeken wat dossiermedewerkers doen bij concrete problemen in het werk. Vervolgens wordt er in paragraaf 7.3 aandacht geschonken aan de wijze waarop medewerkers van Het Kantoor de vereiste competenties leren. Ten slotte wordt er in paragraaf 7.4 gekeken in hoeverre werknemers zelf bereid zijn energie te steken in hun opleiding en hun loopbaanontwikkeling.

\subsection{Wat doen medewerkers bij concrete problemen in het werk?}

Tabel 7.1 geeft een overzicht van wat dossiermedewerkers doen als ze ergens niet uitkomen. lets meer dan de helft van de medewerkers raadpleegt in dat geval een collega. Andere oplossingen zijn het raadplegen van een ervaren collega, de hulp inroepen van een dienstverlenende eenheid of de instructie bekijken. Vrouwen blijken overigens vaker collega's te raadplegen dan mannen. Het lijkt er overigens op dat dossiermedewerkers het raadplegen van collega's soms ervaren als een zwakte-aanbod. Dit blijkt uit het feit dat zowel mannen als vrouwen tegenover de enquêtrice sneller geneigd zijn om te melden dat ze collega's raadplegen dan tegenover de enquêteur.

Tabel 7.1

Wat doen dossiermedewerkers als ze er niet uitkomen?

\begin{tabular}{lccc}
\hline & $\begin{array}{c}\text { Man } \\
\%\end{array}$ & $\begin{array}{c}\text { Vrouw } \\
\%\end{array}$ & $\begin{array}{c}\text { Totaal } \\
\%\end{array}$ \\
\hline Collega's raadplegen & 54 & 72 & 60 \\
Ervaren collega's raadplegen & 12 & 13 & 12 \\
Dienstverlenende eenheid & 9 & - & 6 \\
Instructie bekijken & 15 & 9 & 13 \\
Overig & 10 & 6 & 9 \\
Totaal & 100 & 100 & 100 \\
\hline
\end{tabular}


Ook de staf van Het Kantoor gaf aan dat het raadplegen van collega's een belangrijke attitude is voor een lerende organisatie waarin mensen voortdurend nieuwe zaken moeten leren. Uit een analyse blijkt dat los van het geslacht, de achtergrondkenmerken van de betrokkenen nauwelijks verband houden met de manier waarop men problemen oplost. Wel blijken medewerkers die door hun manager een goede beoordeling kregen met betrekking tot vakkennis en computervaardigheden vaker een collega te raadplegen, terwijl zij die goed zijn in schrijven of rekenen dit juist minder doen.

Ongeveer een op de drie medewerkers geeft aan problemen te hebben gehad met de veranderingen die de afgelopen tijd bij Het Kantoor hebben plaatsgevonden. Tabel 7.2 laat zien in welke mate de medewerkers bij deze veranderingen ook hulp hebben gekregen. Terwijl de organisatorische veranderingen de meeste problemen met zich meebrachten, blijkt juist bij deze verandering de hulp die wordt geboden aan de medewerkers het minste te zijn. Ongeveer de helft van de betrokkenen blijkt (vrijwel) geen hulp te hebben gekregen om zich aan te passen aan de organisatorische veranderingen. Bij automatisering is de hulp die wordt geboden groter. Hier krijgt ongeveer de helft van de medewerkers enige hulp en nog eens een kwart (zeer) veel hulp. Veranderingen in de regelgeving blijken nog beter ondersteund te worden.

Tabel 7.2

De mate waarin medewerkers hulp hebben gekregen bij de veranderingen

\begin{tabular}{lccc} 
& Regelgeving & Automatisering & $\begin{array}{c}\text { Organisatorische } \\
\text { veranderingen } \\
\%\end{array}$ \\
& $\%$ & $\%$ & 22 \\
(Zeer) veel & 32 & 23 & 29 \\
Enige & 39 & 48 & 49 \\
(Vrijwel) geen & 29 & 29 & 100 \\
Total & 100 & 100 & \\
\hline
\end{tabular}

Tabel 7.3

De soort hulp die medewerkers hebben gekregen bij de veranderingen

\begin{tabular}{lccc}
\hline & $\begin{array}{c}\text { Regelgeving } \\
\%\end{array}$ & $\begin{array}{c}\text { Automatisering } \\
\%\end{array}$ & $\begin{array}{c}\text { Organisatorische } \\
\text { veranderingen } \\
\%\end{array}$ \\
\hline Collega's & 10 & 13 & 38 \\
Cursus & 36 & 43 & 4 \\
Instructie/voorlichting & 33 & 30 & 21 \\
$\begin{array}{l}\text { Begeleiding } \\
\text { Meer tijd }\end{array}$ & 18 & 13 & 25 \\
Overig & 3 & 3 & 13 \\
Totaal & 100 & 100 & 100 \\
\hline
\end{tabular}


De reden voor deze verschillen in begeleiding kunnen wellicht gevonden worden in de soort hulp die bij de veranderingen belangrijk blijkt te zijn. Tabel 7.3 laat zien dat voor veranderende regelgeving en automatisering cursussen een belangrijke rol spelen. Voor organisatorische veranderingen blijken de collega's een belangrijkere rol te spelen. In alle gevallen wordt begeleiding en instructie/voorlichting als hulp bij de aanpassing genoemd.

Tabel 7.4 laat zien dat bij alle drie de veranderingen meer dan de helft van de betrokkenen vindt dat het aanpassingsproces beter had kunnen verlopen. Bij organisatorische veranderingen is dit percentage met 61 het hoogst. Ook blijkt hier een redelijk omvangrijke groep niet te weten of het aanpassingsproces beter had kunnen verlopen. Kennelijk is bij organisatorische veranderingen minder duidelijk dan bij veranderende regelgeving en automatisering hoe een dergelijk proces ondersteund kan worden.

Tabel 7.4

De mening van de medewerkers over de vraag of de aanpassing (nog) beter had kunnen verlopen

\begin{tabular}{lccc}
\hline & $\begin{array}{c}\text { Regelgeving } \\
\%\end{array}$ & $\begin{array}{c}\text { Automatisering } \\
\%\end{array}$ & $\begin{array}{c}\text { Organisatorische } \\
\text { veranderingen } \\
\%\end{array}$ \\
\hline Ja & 56 & 53 & 61 \\
Nee & 44 & 47 & 28 \\
Weet niet & - & - & 11 \\
Totaal & 100 & 100 & 100 \\
\hline
\end{tabular}

In tabel 7.5 wordt aangegeven welke soort hulp volgens de medewerkers nuttig zou zijn geweest om de aanpassingen beter te laten verlopen. Opmerkelijk is dat hier de verschillen tussen de drie aanpassingen niet erg groot zijn. Begeleiding en aanspreekpunt is doorgaans de belangrijkste hulp, gevolgd door een cursus en instructie/voorlichting. Slechts sporadisch wordt meer tijd als oplossing genoemd.

Tabel 7.5

Wat zou nodig zijn om de aanpassing beter te laten verlopen

\begin{tabular}{lccc}
\hline & $\begin{array}{c}\text { Regelgeving } \\
\%\end{array}$ & $\begin{array}{c}\text { Automatisering } \\
\%\end{array}$ & $\begin{array}{c}\text { Organisatorische } \\
\text { veranderingen } \\
\%\end{array}$ \\
\hline Cursus & 35 & 24 & 24 \\
Instructie/voorlichting & 17 & 24 & 24 \\
Begeleiding/aanspreekpunt & 30 & 38 & 35 \\
Meer tijd & 4 & 5 & 6 \\
Overige & 13 & 10 & 100 \\
Totaal & 100 & 100 & 6 \\
\hline
\end{tabular}


Tabel 7.6 laat zien dat voor de drie belangrijkste veranderingen afzonderlijk steeds ongeveer $20 \%$ van de medewerkers meer hulp had willen ontvangen. Bij Leven betreft dit vooral de veranderingen met betrekking tot de regelgeving; bij Risico is de behoefte aan meer hulp gelijker gespreid, maar ligt de grootste vraag bij hulp bij automatisering. Tabel 7.7 geeft aan hoe de behoefte aan meer hulp verdeeld is over de opleidingsniveaus. Al eerder bleek dat lager opgeleiden meer problemen hebben met veranderingen dan hoger opgeleiden. Dit is met name het geval voor veranderingen in regelgeving en automatisering. Ook in de behoefte aan meer hulp komt dit tot uiting.

Tabel 7.6

Percentage medewerkers met behoefte aan meer hulp bij aanpassingsproces bij Leven en Risico

\begin{tabular}{lccc}
\hline & $\begin{array}{c}\text { Regelgeving } \\
\%\end{array}$ & Automatisering & $\begin{array}{c}\text { Organisatorische } \\
\text { veranderingen } \\
\%\end{array}$ \\
\hline Leven & 27 & $\%$ & 12 \\
Risico & 20 & 18 & 22 \\
\hline
\end{tabular}

Tabel 7.7

Percentage medewerkers met behoefte aan meer hulp bij aanpassingsproces per opleidingsniveau

\begin{tabular}{lccc}
\hline & $\begin{array}{c}\text { Regelgeving } \\
\%\end{array}$ & $\begin{array}{c}\text { Automatisering } \\
\%\end{array}$ & $\begin{array}{c}\text { Organisatorische } \\
\text { veranderingen } \\
\%\end{array}$ \\
\hline Geen of VBO & 44 & 22 & 22 \\
MAVO/MULO & 24 & 28 & 20 \\
HAVONWO & 26 & 16 & 21 \\
MBO & 21 & 21 & 12 \\
HBONW & 8 & 15 & 15 \\
\hline
\end{tabular}

\subsection{Cursussen en leerbronnen van competenties}

In dit deel van het hoofdstuk wordt ingegaan op de wijze waarop medewerkers van Het Kantoor de vereiste competenties leren. Tabel 7.8 geeft aan welk soort cursussen de dossiermedewerkers volgen. Cursussen over pensioenen en sociale verzekeringen blijken bijna de helft van het totaal aantal cursussen uit te maken. Cursussen die betrekking hebben op automatisering, worden ook veel gevolgd.

Veel cursussen die van belang zijn voor de directe uitoefening van de functie worden gedurende werktijd verricht. Meer op algemene ontwikkeling gerichte opleidingen die zowel voor Het Kantoor als voor de ontwikkeling van de betreffende medewerker van belang kunnen zijn, worden echter vaak in eigen tijd gevolgd. Het is echter niet voor iedereen mogelijk om thuis in de avonduren of het weekend een cursus te volgen. 
Tabel 7.8

Gemiddeld aantal cursussen per medewerker

\begin{tabular}{lccc}
\hline Thema & Leven & Risico & Totaal \\
\hline Pensioen/verzekering & 1,63 & 0,92 & 1,27 \\
Communicatie & 0,47 & 0,10 & 0,28 \\
Automatisering & 0,47 & 0,52 & 0,49 \\
Boekhouden/administratie & 0,18 & 0,28 & 0,23 \\
Management & 0,10 & 0,04 & 0,07 \\
Algemeen & 0,08 & 0,06 & 0,07 \\
Veel korte interne cursussen & 0,24 & 0,36 & 0,30 \\
Overig & 0,29 & 0,14 & 2,21 \\
Totaal & 3,47 & 2,42 & 2,94 \\
\hline
\end{tabular}

Tabel 7.9

Leidt het volgen van een cursus tot praktische problemen?

\begin{tabular}{lc}
\hline Praktische problemen & $\%$ \\
\hline Zeer veel & 2 \\
Veel & 14 \\
Enige & 31 \\
Vrijwel geen & 24 \\
Geen enkele & 28 \\
Totaal & 100 \\
\hline
\end{tabular}

Tabel 7.10

Belangrijkste belemmeringen bij het volgen van een cursus

\begin{tabular}{lc}
\hline Belemmeringen & $\%$ \\
\hline Drukte op het werk & 39 \\
Prive-situatie, geen zin & 46 \\
Bezig met een cursus & 10 \\
Te moeilijk & 5 \\
Totaal & 100 \\
\hline
\end{tabular}

Tabel 7.9 laat zien dat ongeveer de helft van de dossiermedewerkers op zijn minst enige problemen voorziet als men een dergelijke cursus zou gaan volgen. Tabel 7.10 laat zien dat meestal de thuissituatie de belemmeringen veroorzaakt. De argumenten lopen uiteen van drukte vanwege de kinderen, ziekte echtgenoot tot De rol van managers bij dit nieuwe 'leergedrag' is essentieel omdat het initiatief om werk anders aan te pakken vaak niet vanuit de medewerkers zelf komt. Managers zijn tot nu toe niet echt stimulator of facilitator van leren geweest, ook door de dagelijkse drukte. Maar als er wel tijd was, speelden ze die rol ook niet voldoende. Om 'evaluerend leren vanuit de praktijk' binnen Risico gemeengoed te maken zijn er nieuwe managers aangesteld. 
$\mathrm{Na}$ een tijd van relatief beperkte aandacht voor het opleiden van het eigen personeel, staan opleidingen sinds enkele jaren bij Het Kantoor weer volop in de belangstelling. Die verslapte aandacht in het verleden heeft er toe geleid dat het informatiesysteem waarin de opleidingen van werknemers geregistreerd worden, een tijd lang niet nauwkeurig is bijgehouden. Vandaar dat hier een inhaalslag plaats zal vinden; betrouwbare informatie over opleidingen vormt immers een belangrijke pijler in het nog verder in te voeren competentiemanagement. De hernieuwde belangstelling voor opleidingen uit zich verder doordat er in het jaarplan 2000 expliciet aandacht wordt besteed aan opleidingsplannen en dat het bedrijf voor zichzelf een kwantitatieve opleidingsdoelstelling formuleert. Het management streeft ernaar $3 \%$ van de loonsom (out-of-pocket) uit te geven aan opleidingen. Het aangeven van een dergelijke doelstelling is echter niet genoeg om ervoor te zorgen dat het geld ook werkelijk voor opleidingen gebruikt wordt; tot nu toe werd slechts ongeveer de helft van de beschikbare budgetten werkelijk besteed.

Zowel informatisering als veranderende wetgeving maken scholing van medewerkers een noodzaak. Het is vooral heel veel nieuwe vakkennis, die in Het Kantoor nodig is, maar ook andere vaardigheden worden steeds belangrijker. Een voorbeeld van dergelijke vaardigheden is klantvriendelijkheid, die bij Leven onlangs door middel van een 'cafétraining' integraal is verbeterd. De aandacht voor opleidingen is ook binnen Leven pas enkele jaren geleden teruggekomen. Daarvoor had men te veel vertrouwen in de systemen, die opleidingen overbodig zouden maken.

Bij Leven heerst bij het management de opvatting dat het erg belangrijk is dat opleidingen goed en vanuit het perspectief van de medewerker interessant opgezet moeten zijn. Saai en droog studiemateriaal dat op klassieke wijze wordt overgebracht aan de medewerkers wordt daarbij verworpen. Hoewel een deel van het leren toch altijd saai zal blijven ('stampen'), zijn interactieve leerwijzen waarbij gebruik gemaakt wordt van diverse hulpmiddelen volgens een aantal managers de opleidingen van de toekomst. Verder is het van belang het draagvlak voor de cursussen bij medewerkers te vergroten door ze te betrekken bij de opzet van nieuwe trainingen.

Volgens het management van Leven is een deel van de dossiermedewerkers huiverig voor het volgen van opleidingen. Dit kan een aantal oorzaken hebben, zoals bijvoorbeeld slechte ervaringen in het verleden. Zo is er in 1996, een fiasco geweest met een nieuw computersysteem, dat erg veel beloofde, zoals bijvoorbeeld scholing die volledig via het nieuwe systeem zou kunnen plaatsvinden. Voor de invoering van nieuwe wetgeving voor Leven was al $25 \%$ van het personeel overtollig verklaard en deze groep werd voorbereid op een carrière in de buitenwereld. Het nieuwe systeem is echter niet op tijd klaargekomen, met als gevolg dat de oude systemen moesten worden aangepast. Een en ander heeft tot gevolg gehad dat 'de sfeer danig was verpest'.

Overigens verdwijnt de huivering voor nieuwe cursussen vaak wanneer het management aangeeft dat medewerkers een cursus niet moeten volgen omdat ze 
iets niet kunnen, maar dat de cursus gericht is op het verbeteren van vaardigheden. Ook gedurende het verloop van een cursus blijkt meestal dat de aanvankelijke huivering vrij vlot verdwijnt wanneer de opleiding goed is en gegeven wordt door kundige docenten. Het stimuleren van de transfer van de opleiding naar de werksituatie is daarnaast een aspect dat volgens sommige managers extra aandacht behoeft.

Ook bij Risico is er, gezien de complexiteit van de werkzaamheden, te weinig in opleidingen geïnvesteerd, iets dat vooral te wijten is aan de snelheid van veranderingen en de drukte in het dagelijkse werk. Het was gaandeweg in de praktijk leren, 'laat maar gaan met die kar'. Dat er sprake is van 'achterstallig onderhoud' valt ook af te leiden aan de hand van de personeelsdossiers en de veelal niet gerealiseerde opleidingsbudgetten. Om de situatie in de toekomst te kunnen verbeteren is er onlangs een uit twee stappen bestaand integraal opleidingsplan voorgesteld. De eerste stap is het sterk maken van de medewerkers in het vak, zowel door vakgerichte als ook wat meer algemene scholing. Als de werknemers daar doorheen zijn moeten ze worden voorbereid op een stukje ondernemingsgeest zodat mensen meer uit zichzelf kunnen halen.

Het is wel van belang bij de invulling van de opleidingsbehoefte dat leren 'van twee kanten moet komen'. Dit betekent dat het leergedrag van mensen gestimuleerd moet worden, iets dat binnen Risico niet vanzelf ontstaat. Ook aan de inhoud van scholing moet nog veel veranderen. Scholing is nog te veel op het vak gericht, en te weinig op meer algemene kennis (bijvoorbeeld lerend vermogen). Daarbij moeten ook de processen kritisch onder de loep worden genomen. Initiatieven op dit vlak worden ook al ontplooid.

Zo wordt er bijvoorbeeld geanalyseerd hoe de grote hoeveelheid klachten verminderd kan worden, door te kijken naar wat de oorzaken van die klachten zijn. Deze manier van werken is nog geen gemeengoed binnen Risico; er wordt nog steeds teveel nadruk gelegd op regels en procedures.

De rol van managers bij dit nieuwe 'leergedrag' is essentieel omdat het initiatief om werk anders aan te pakken vaak niet vanuit de medewerkers zelf komt. Managers zijn tot nu toe niet echt stimulator of facilitator van leren geweest, ook door de dagelijkse drukte. Maar als er wel tijd was, speelden ze die rol ook niet voldoende. Om 'evaluerend leren vanuit de praktijk' binnen Risico gemeengoed te maken zijn er nieuwe managers aangesteld.

Opleiden is bij Het Kantoor erg belangrijk geworden omdat de vele ontwikkelingen die hebben plaatsgevonden de benodigde skills van de medewerkers ingrijpend wijzigen. Het management geeft ook aan dat er in het verleden een scholingsachterstand is opgebouwd bij zowel medewerkers als managers. Dat maakt de behoefte aan scholing nog acuter. Het is de kunst om deze achterstanden snel weg te werken, maar de realiteit is dat scholingstrajecten waarbij medewerkers voor langere tijd uit het productieproces gehaald worden niet mogelijk zijn; het gewone werk moet immers ook op tijd af. Of, zoals een Risico- manager het treffend verwoordde: 'tijdens de verbouwing gaat de verkoop door'. 
Tabel 7.11 laat zien dat de meeste dossiermedewerkers nog steeds voorkeur geven aan een traditionele leerwijze in de vorm van lessen. Schriftelijke cursussen of cursussen via internet worden nauwelijks op prijs gesteld.

Tabel 7.11

Als $u$ een cursus thuis zou willen volgen wat zou dan uw voorkeur hebben?

\begin{tabular}{lc}
\hline Voorkeur & $\%$ \\
\hline Lessen & 71 \\
Schriftelijk & 15 \\
Internet & 4 \\
Geen voorkeur & 10 \\
Totaal & 100 \\
\hline
\end{tabular}

Tot slot van deze paragraaf wordt voor de verschillende werkzaamheden en facetten van het werk nagegaan waar mensen dit geleerd hebben. Tabel 7.12 geeft de belangrijkste leerbronnen voor de verschillende werkzaamheden, in volgorde van belangrijkheid weer. Indien dit mogelijk is wordt hierbij een onderscheid gemaakt tussen mensen die goed zijn in het betreffende onderdeel (minstens een 4 op de 5-puntschaal) en zij die dat niet zijn.

Uit de tabel komt naar voren dat zelfstudie de belangrijkste leerbron is voor het toekennen. Daarnaast geeft ongeveer een kwart van de dossiermedewerkers aan dat zij deze bezigheid met name geleerd hebben in een eerdere functie. Bij de beheerswerkzaamheden worden eerdere functies veelal als belangrijkste leerbron genoemd. Daarbij valt het op dat mensen die op het gebied van beheerswerkzaamheden minder goed scoren deze leerbron minder vaak de belangrijkste vinden dan dossiermedewerkers die wel goed scoren ( $32 \%$ versus $43 \%$ ). Voor de leerbron 'altijd al goed in geweest' geldt juist het tegenovergestelde. Werknemers die op het vlak van beheerswerkzaamheden minder goed scoren geven vaker aan dat ze er altijd al goed in zijn geweest dan medewerkers die minder goed scoren op dit punt.

Corresponderen is een werkzaamheid die voor het grootste deel geleerd wordt in de praktijk van het dagelijks werk. Een kwart van de medewerkers geeft namelijk aan dat ze deze bezigheid met name van hun collega's of hun baas hebben geleerd. Ook een eerdere functie treedt vaak op als belangrijkste leerbron (17\%).

Inlichtingen verstrekken is een bezigheid waarvan veel dossiermedewerkers aangeven dat ze er altijd al goed in zijn geweest. Een deel van de medewerkers geeft weliswaar aan dit met name geleerd te hebben van een bedrijfscursus of van collega's of de werkbaas, maar het overgrote deel van de medewerkers vindt dat ze inlichtingen kunnen verstrekken, dat als een relationele vaardigheid gezien kan worden, omdat ze er altijd al goed in zijn geweest. 


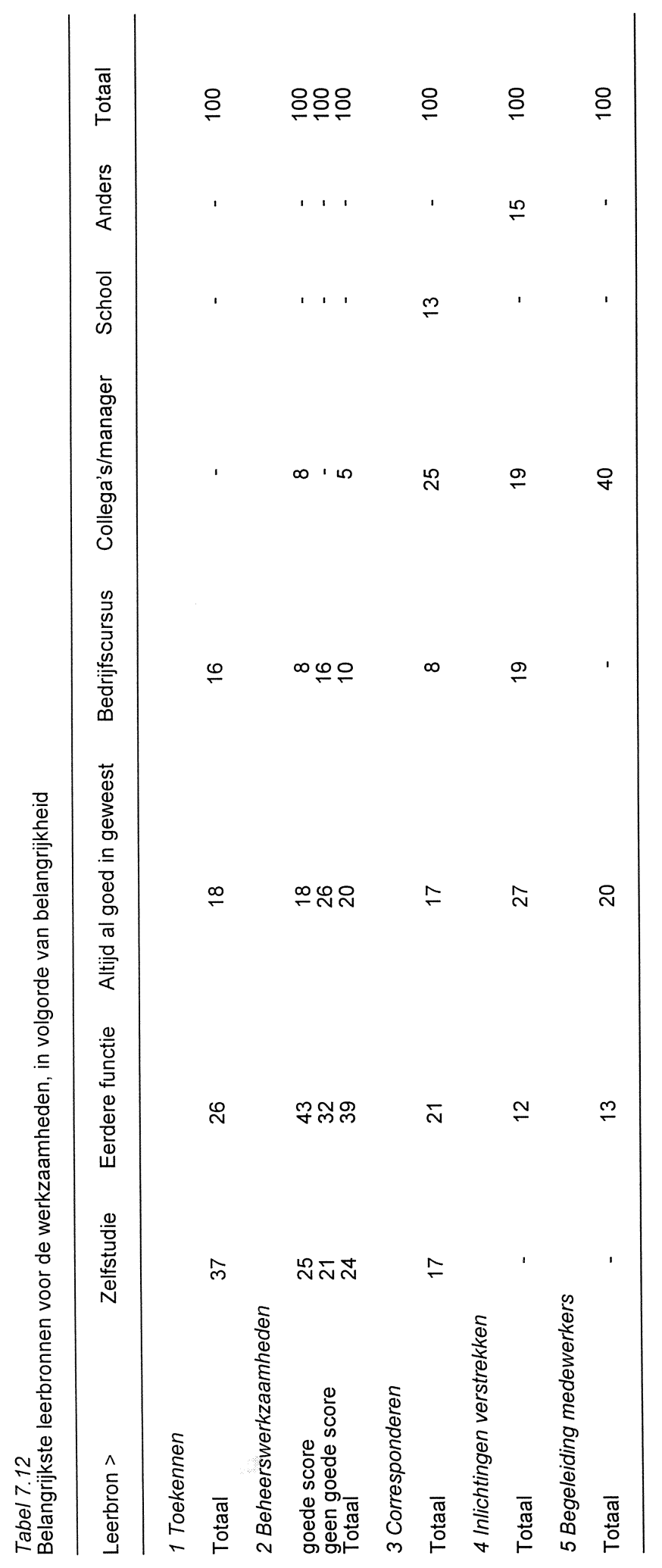


De begeleiding van medewerkers is een voorbeeld van een activiteit die tijdens de dagelijkse werkzaamheden wordt aangeleerd. Maar liefst $40 \%$ van de dossiermedewerkers geeft aan dat de belangrijkste leerbron voor het begeleiden van medewerkers de collega's of de werkbaas is.

Tabel 7.13 gaat op vergelijkbare wijze in op de leerbronnen van de verschillende aspecten van het werk.

Uit de tabel komt duidelijk naar voren dat er grote verschillen zijn tussen de leerbronnen van de verschillende aspecten van het werk. Zo is bij specialistische kennis bijvoorbeeld het leren van collega's en de werkbaas erg belangrijk. Voor aspecten die sterk samenhangen met relationele vaardigheden (zoals bijvoorbeeld instructies, training of les geven en adviseren en zorg dragen voor klanten) is juist zelfstudie de belangrijkste leerbron. Computergebruik wordt vooral aangeleerd door bedrijfscursussen, hoewel ook hier zelfstudie als leerbron vaak genoemd wordt. School wordt het meest genoemd als belangrijkste leerbron voor het schrijven en het maken van eenvoudige berekeningen. Plannen, daarentegen, wordt veelal geleerd door zelfstudie.

Ook tussen dossiermedewerkers die een goede score hebben op bepaalde aspecten en diegenen die minder scoren zijn er soms grote verschillen. Zo geeft $15 \%$ van de medewerkers met een goede score voor adviseren en zorg dragen voor klanten aan, deze vaardigheid voor het belangrijkste deel geleerd te hebben door een bedrijfscursus, terwijl dit percentage voor de medewerkers met een lage score slechts $5 \%$ is. Eenvoudige berekeningen worden door minder goede werknemers veelal geleerd door te rade te gaan bij collega's of werkbaas, terwijl een aantal dossiermedewerkers die goed zijn in eenvoudige berekeningen aangeven dat voor hen een eerdere functie de belangrijkste leerbron was, of dat ze er altijd al goed in waren.

Aan de dossiermedewerkers is ook gevraagd in hoeverre ze denken nog te kunnen bijleren op het vlak van de aspecten in het werk, en hoe dat volgens hen het best zou kunnen. Hieruit komt naar voren dat van degenen die denken nog bij te kunnen leren met betrekking tot instrueren $61 \%$ hiervoor een cursus wil, en $23 \%$ ervaring of praktijk. Van degenen die denken nog bij te kunnen leren op het vlak van het adviseren en zorgdragen voor klanten denkt $57 \%$ hierbij aan een cursus/opleiding en $25 \%$ aan ervaring/praktijk. Mensen die minder goed zijn in adviseren en zorgdragen voor klanten noemen vaker collega's of hun manager als extra leerbron. Van degenen die denken nog extra specialistische kennis te vergaren noemt $61 \%$ cursus. Degenen die beter zijn in specialistische kennis noemen vaker praktijk of zelfstudie. 


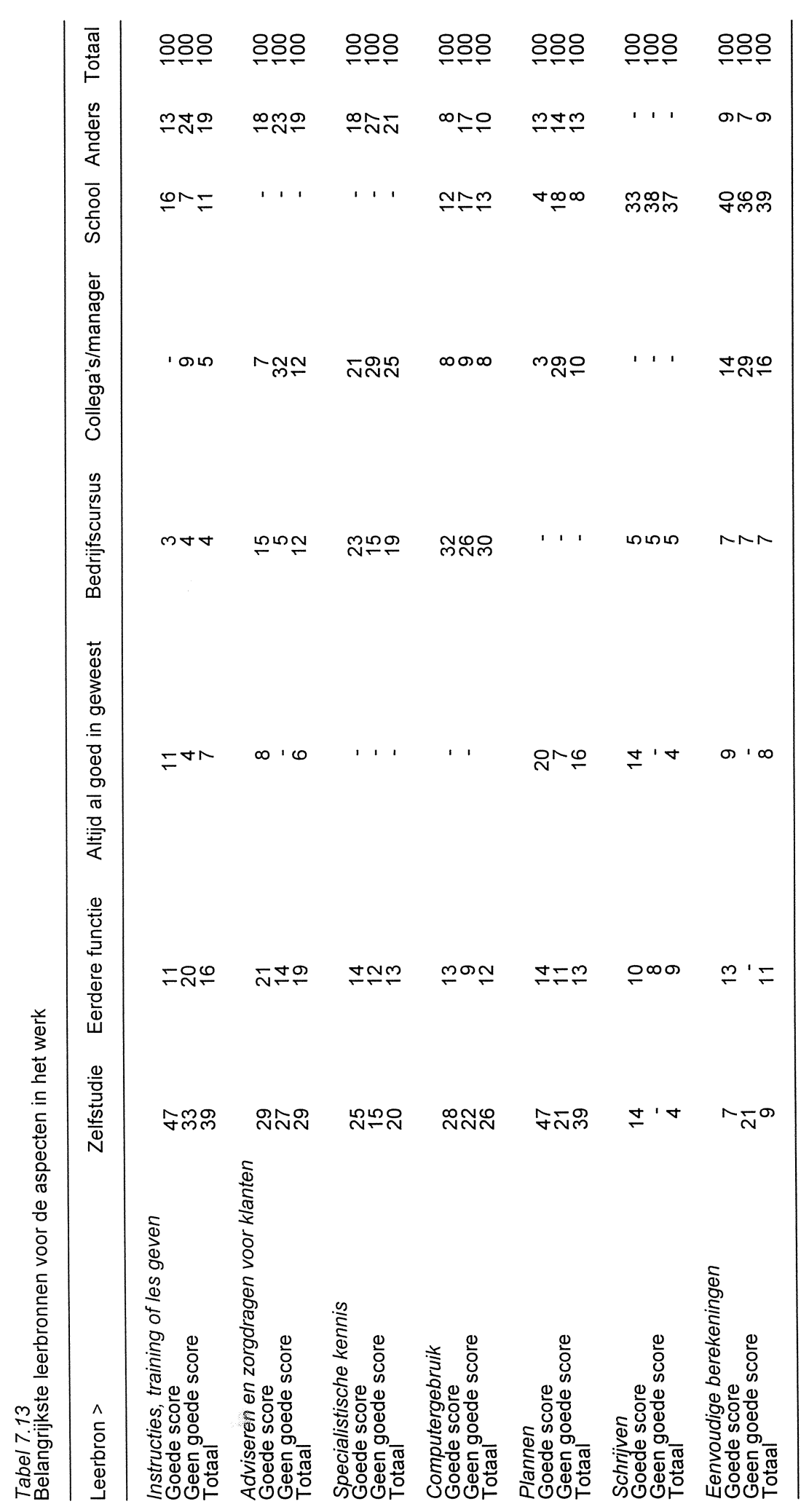


Van degenen die nog denken te kunnen bijleren op het gebied van computergebruik noemt $78 \%$ een cursus. Mensen die minder goed zijn noemen in $91 \%$ van de gevallen een cursus, de beteren in $74 \%$.

Zij noemen ook ervaring, collega's en zelfstudie. Additionele planningsvaardigheden denkt men vooral te kunnen leren via een cursus $(39 \%)$ of praktijkervaring $(34 \%)$. Betere planners noemen ook het leren van collega's (19\%) als mogelijke leerbron. Beter leren schrijven denken de dossiermedewerkers vooral te kunnen doen door het volgen van een cursus $(73 \%)$. Medewerkers die goed scoren op het gebied van schrijfvaardigheid denken daarnaast ook te kunnnen bijleren door collega's te raadplegen.

Al met al valt met name op dat medewerkers relatief weinig aangeven dat ze dingen die voor het werk van belang zijn hebben geleerd van een cursus. Als hen echter gevraagd wordt hoe ze denken meer te kunnen leren blijken ze echter toch vaak een cursus aan te geven. Deze discrepantie kan twee dingen betekenen. Ten eerste zou het zo kunnen zijn dat er voor de medewerkers geen geschikte cursussen beschikbaar zijn. Ten tweede is het echter ook zeer goed mogelijk dat medewerkers ten onrechte toch nog hoge verwachtingen van cursussen hebben, terwijl deze in de praktijk minder op leveren dan wellicht wordt verwacht. Deze mogelijk verklaringen samennemend, lijkt de conclusie te mogen worden getrokken dat gerichte werkervaring of cursussen die meer geënt zijn op de werkpraktijk wellicht meer te bieden hebben dan traditionele cursussen.

\subsection{Aspiraties en zelfontwikkeling}

Naast kwantitatieve kengetallen over competentie-ontwikkeling (zoals bijvoorbeeld het aantal opleidingen dat een werknemer volgt) speelt ook de mate waarin werknemers gemotiveerd zijn een belangrijke rol bij het realiseren van competentieverbeteringen. In deze paragraaf worden de aspiraties van de werknemers en de mate waarin ze bereid zijn inspanningen te leveren voor hun eigen ontwikkeling onder de loep genomen. Eerst komen de aspiraties aan bod. Vervolgens wordt er gekeken hoe het met de bereidheid van de werknemers staat om zelf initiatief te nemen en verantwoordelijkheid te dragen voor hun eigen scholing en hun loopbaanontwikkeling.

\section{Aspiraties}

Het grootste deel van de dossiermedewerkers (87 procent) hoopt over tien jaar nog te werken. Ongeveer de helft van de werknemers geeft aan dat ze dan full-time werkzaam willen zijn. Van diegenen die over tien jaar niet meer willen werken geeft vrijwel iedereen aan dat men tegen die tijd met pensioen of vut wil zijn. Aan degenen die over 10 jaar met pensioen of vut zullen zijn is gevraagd welke positie zij vlak voor hun vertrek ambiëren. 
Uit een enquête komt naar voren dat diegenen die over tien jaar nog niet aan pensioen of vut toe zijn voor het merendeel $(72 \%)$ een hoger functieniveau dan nu ambiëren. Voor de mensen die dan wel rond hun pensioengerechtigde leeftijd zijn, hoeft dat in het algemeen niet zo nodig meer. Van deze groep mensen geeft $55 \%$ aan dan nog graag te willen werken op het huidige functieniveau. Het valt op dat de gewenste baan voor de mensen die over tien jaar nog niet met pensioen gaan veel vaker binnen de financiële dienstverlening is dan voor hun collega's die wel over afzienbare tijd pensioengerechtigd worden.

Tabel 7.14

Aspiratie naar functie over 10 jaar

\begin{tabular}{lc}
\hline Functie & $\%$ \\
\hline Medewerker & 26 \\
Adviseur & 12 \\
Senior-Medewerker & 12 \\
Manager & 8 \\
lets geheel anders & 14 \\
Overig & 11 \\
Weet niet & 16 \\
Totaal & 100
\end{tabular}

In tabel 7.14 wordt de geaspireerde functie van de medewerkers weergegeven. Ongeveer een kwart van de medewerkers wil graag de huidige functie behouden. Een volgende $25 \%$ wil adviseur of senior-medewerker worden, wat een verzwaring van de huidige baan zou betekenen. Acht procent van de medewerkers wil manager worden, terwijl $14 \%$ aangeeft iets geheel anders te willen gaan doen. Uit analyses blijkt verder dat ruim $85 \%$ hoopt dat de toekomstige functie bij Het Kantoor zal zijn.

Tabel 7.15

Acties om gewenste functie te bereiken

\begin{tabular}{lc}
\hline Actie & $\%$ \\
\hline Opleidingen volgen & 46 \\
Solliciteren & 17 \\
Oriënteren & 10 \\
Hard werken/initiatief tonen & 27 \\
Totaal & 100 \\
\hline
\end{tabular}

Aan de dossiermedewerkers is ook gevraagd of ze iets ondernemen om de gewenste positie in de toekomst te bereiken. Zestig procent gaf aan dit te doen. Wat men precies doet staat in tabel 7.15 weergegeven.

Uit de tabel komt naar voren dat $46 \%$ de gewenste functie probeert te bereiken door opleidingen te volgen. Een ander substantieel deel van de medewerkers $(27 \%)$ probeert het gewenste doel te bereiken door hard te werken en initiatief te tonen. 
Tabel 7.16

Initiatief en verantwoordelijkheid voor scholing en loopbaanontwikkeling

\begin{tabular}{|c|c|c|c|c|c|c|c|}
\hline Aspect & ++ & + & $+1-$ & - & -- & $?$ & Totaal \\
\hline \multicolumn{8}{|l|}{ Initiatief } \\
\hline $\begin{array}{l}\text { Voor eigen bijscholing nemen? } \\
\text { Voor eigen loopbaanontwikkeling nemen? }\end{array}$ & $\begin{array}{l}15 \\
28\end{array}$ & $\begin{array}{l}64 \\
54\end{array}$ & $\begin{array}{l}7 \\
6\end{array}$ & $\begin{array}{r}11 \\
8\end{array}$ & $\begin{array}{l}1 \\
1\end{array}$ & $\begin{array}{l}2 \\
3\end{array}$ & $\begin{array}{l}100 \\
100\end{array}$ \\
\hline $\begin{array}{l}\text { Verantwoordelijkheid } \\
\text { Voor eigen bijscholing dragen? } \\
\text { Voor eigen loopbaanontwikkeling dragen? }\end{array}$ & $\begin{array}{l}12 \\
17\end{array}$ & $\begin{array}{l}70 \\
65\end{array}$ & $\begin{array}{l}5 \\
8\end{array}$ & $\begin{array}{l}12 \\
10\end{array}$ & $\begin{array}{l}1 \\
0\end{array}$ & $\begin{array}{l}0 \\
0\end{array}$ & $\begin{array}{l}100 \\
100\end{array}$ \\
\hline $\begin{array}{l}++ \text { geheel eens } \\
+\quad=\text { eens } \\
+/-=\text { noch eens, noch oneens } \\
-\quad=\text { oneens } \\
--\quad=\text { geheel oneens } \\
? \quad=\text { geen mening/weet niet }\end{array}$ & & & & & & & \\
\hline
\end{tabular}

\section{Zelfontwikkeling}

Aan de medewerkers is ook gevraagd hoe ze in het algemeen staan tegenover bijscholing en loopbaanontwikkeling. In tabel 7.16 wordt de mate van initiatief en verantwoordelijkheid voor de eigen scholing en loopbaan gepresenteerd. Het valt op dat het gros van de medewerkers het eens of geheel eens is met de stellingen. In andere analyses is ook gekeken of de resultaten samenhangen met achtergrondkenmerken van werknemers. Wanneer het gaat om het initiatief tot het volgen van bijscholing valt het op dat mensen met opleidingsachtergrond MAVO of MULO veel vaker aangeven het hier oneens of geheel oneens mee te zijn dan werknemers met een ander opleidingsniveau. Een andere markante uitkomst is dat mannen op alle vier de aspecten die in tabel 7.16 genoemd worden minder vaak geheel eens of eens antwoorden dan vrouwen. Verder kan uit de gegevens worden opgemaakt dat jongere werknemers vooral erg sterk zijn wat betreft het initiatief nemen tot scholing en loopbaanontwikkeling. Qua verantwoordelijkheid scoort voor bijscholing de middengroep het best, terwijl de oudere werknemers zich het meest verantwoordelijk voelen voor hun loopbaanontwikkeling. 


\section{Een balans}

In het afgelopen decennium hebben er bij een groot aantal bedrijven veranderingen plaatsgevonden die tot gevolg hadden dat de kennis waarover mensen beschikten in een snel tempo verouderd raakte. Mensen die hun vak goed beheersten dreigden daardoor hun comfortabele positie te verliezen. Met name de introductie van computers en organisatorische veranderingen betekenden voor een groot aantal bedrijven dat er ingrijpende aanpassingen waren vereist. Daarnaast kregen veel bedrijven, door een toenemende nationale en internationale concurrentie, noodgedwongen te maken met veranderingen in het productieproces.

Om adequaat te kunnen blijven functioneren op de arbeidsmarkt spelen de kennis en vaardigheden waarover mensen beschikken een belangrijke rol. De laatste tijd is de maatschappelijke interesse voor kennis als economische factor sterk toegenomen. Dit uit zich bijvoorbeeld door de vele nationale en internationale initiatieven gericht op scholing van werkenden en werklozen.

De veranderingen hebben op het niveau van individuele bedrijven tot gevolg dat het beleid steeds vaker in het teken staat van het behouden en vergroten van het menselijk kapitaal van het personeelsbestand. Dit is ook het geval bij Het Kantoor, het bedrijf dat in dit rapport centraal staat. Een aantal medewerkers en hun managers van Het Kantoor is mondeling geënquêteerd om een aantal vragen, die direct gerelateerd zijn aan de kernveronderstellingen zoals die in het Werkgelegenheid- en Scholing-Observatorium van het $\mathrm{ROA}^{2}$ gehanteerd worden, op zeer gedetailleerde wijze te kunnen onderzoeken. Het grote voordeel van de aanpak van dit onderzoek is dat het mogelijk is de bestaande denkkaders over de betekenis van veranderingen die een organisatie ondergaat expliciet te toetsen zonder dat daarbij vooraf specifieke veronderstellingen moeten worden gemaakt.

Het Kantoor is een onderneming in de financiële sector, die uit twee bedrijfsonderdelen bestaat, Risico en Leven. De werkzaamheden van de grootste groep werknemers van Het Kantoor - de zogenaamde dossiermedewerkers - zijn in beide bedrijfsonderdelen gelijksoortig. De kerntaak van deze dossiermedewerkers is het behandelen van aanvragen voor uitkeringen. Dossiermedewerkers werken in teams van 10 tot 25 personen onder leiding van een manager.

Het Kantoor staat midden in de overgang van een bedrijf met een vaste, door regelgeving vastgelegde groep klanten, naar een marktgerichte onderneming die moet concurreren met vergelijkbare ondernemingen. Daarnaast heeft Het Kantoor de laatste jaren met nog een tweetal andere belangrijke veranderingen te maken gehad. In de eerste plaats is het werk van de dossiermedewerkers sterk van karakter veranderd door de introductie van informatie- en communicatietechnologie en het toenemend gebruik daarvan. Ook is er op het gebied van vakinhoudelijke 
regelgeving, die voor het werk van de dossiermedewerkers erg belangrijk is, veel veranderd. Omdat er de laatste jaren bij Het Kantoor zoveel veranderd is, zijn de ontwikkelingen in dit bedrijf en de gevolgen daarvan voor de medewerkers in dit rapport uitvoerig aan de orde gekomen, waarbij de nadruk met name lag op kwalificatieproblemen en de oorzaken en gevolgen daarvan.

Om eventuele kwalificatieproblemen te identificeren is het allereerst van belang een goed beeld te krijgen van de competenties van de medewerkers. In hoofdstuk 3 is derhalve het belang van een aantal facetten van het werk van dossiermedewerker in kaart gebracht. Belangrijke facetten van het werk van de dossiermedewerker zijn het werken met een computer, nauwkeurig werken en het maken van berekeningen.

Daarnaast is de kwaliteit van de werknemers op deze facetten ingeschat door zowel de medewerker zelf als ook zijn manager hierover te ondervragen. Uit de analyses in dit hoofdstuk bleek onder meer dat de oordelen over competenties tussen managers en medewerkers lang niet altijd parallel lopen. Zowel de medewerkers zelf als hun managers lijken geen goed beeld te hebben van de sterke en zwakke punten van de dossiermedewerkers. Managers hebben weliswaar een indruk van het algehele functioneren van de medewerkers, maar zijn niet altijd in staat aan te geven wat de specifieke competenties van een medewerker zijn.

Als er zich in een bedrijf competentieproblemen voordoen zijn er in principe twee oplossingen denkbaar: of de medewerker past zijn competenties aan, of het bedrijf past de werkzaamheden aan die de betrokkene moet uitoefenen. $\mathrm{Na}$ de analyse van de competenties waarover de dossiermedewerkers beschikken in hoofdstuk 3 , wordt in het vierde hoofdstuk de allocatie van het werk onder de loep genomen. Hierbij wordt gekeken naar twee aspecten: werktijd en overwerk en de taakverdeling.

De dossiermedewerkers van Het Kantoor hebben veelal een full time aanstelling van 36 uur en werken gemiddeld 2 uur per week over. Laag opgeleiden werken gemiddeld minder over dan hoogopgeleiden en mensen van middelbare leeftijd (36-45) werken gemiddeld minder over dan ouderen. Overwerk blijkt sterk samen te hangen met de competenties waarover mensen beschikken. Zo werkt bijvoorbeeld iemand met een goede waardering voor vakkennis meer over dan iemand met een slechte waardering op dat vlak.

Toekennen en beheerswerkzaamheden zijn de door de dossiermedewerkers meest genoemde werkzaamheden. Niet iedere ondervraagde medewerker noemt echter dezelfde werkzaamheden. Uit analyses blijkt dat het vooral de competenties zijn waarover mensen volgens hun afdelingshoofd beschikken die bepalen welke werkzaamheden ze uitvoeren. Bij de werkzaamheden wordt blijkbaar rekening gehouden met de aanwezige competenties bij de medewerkers.

In hoofdstuk 5 wordt ingegaan op de wijze waarop dossiermedewerkers zich aanpassen aan de veranderingen die binnen de organisatie plaatsvinden. Eerst wordt er echter kort ingegaan op de inwerktijd van de werknemers. Opvallende re- 
sultaten zijn hier dat vrouwen een veel kortere inwerkperiode aangeven dan mannen. De volgens de werknemers benodigde inwerktijd voor de functie van dossiermedewerker blijkt niet gerelateerd te zijn aan de competenties waarover de werknemers beschikken.

De meeste dossiermedewerkers vinden dat het werk bij Het Kantoor de afgelopen jaren sterk veranderd is en verwachten ook in de toekomst nog ingrijpende veranderingen. De drie meest genoemde veranderingen zijn: regelgeving, automatisering en organisatorische veranderingen. Laatstgenoemde veranderingen worden als meest problematisch ervaren. De moeite die men ervaart bij veranderingen blijkt onder meer afhankelijk van het bedrijfsonderdeel en de opleidingsachtergrond. Wanneer gevraagd wordt naar de belangrijkste problemen die de werknemers hebben ervaren bij de meest voorkomende veranderingen blijken dit vooral problemen in de sfeer van omschakeling (bijvoorbeeld naar nieuwe computersystemen) en vakinhoudelijke aspecten te zijn.

Hoewel tekortschietende competenties en problemen bij het uitoefenen van het werk nog niet onmiddellijk hoeven te betekenen dat de positie van de betrokkene binnen het bedrijf in gevaar komt, is het toch interessant om een beeld te krijgen van de positie van de dossiermedewerkers bij Het Kantoor. Dit werd in hoofdstuk 6 onderzocht aan de hand van de inschattingen van werknemers met betrekking tot de kans van het vinden van vergelijkbaar werk en het risico op werkloosheid. Hoog opgeleiden blijken de kans op het vinden van vergelijkbaar werk hoog in te schatten; ouderen schatten deze kans aanzienlijk geringer in. Wanneer gekeken wordt naar het risico op werkloosheid blijkt dat vooral middelbaar opgeleiden pessimistisch zijn.

Moeite met het vinden van een nieuwe vergelijkbare baan blijkt ook af te hangen van de mate waarin medewerkers moeite hebben met bepaalde veranderingen. Zo geeft bijvoorbeeld $93 \%$ van de dossiermedewerkers, die problemen hebben (gehad) met veranderingen in regelgeving, aan dat ze denken moeite te hebben met het vinden van een nieuwe baan. Voor medewerkers die met die veranderingen geen moeite hadden, bedraagt dit percentage slechts 55 .

Uit een analyse in het tweede deel van hoodstuk 6 blijkt dat competentieproblemen nauwelijks samenhangen met het risico dat mensen denken te lopen om hun baan te verliezen. Als een bepaalde medewerker echter ontslagen zou worden, dan zijn de competenties en de leeftijd waarschijnlijk wel bepalend voor de mogelijkheden op de externe arbeidsmarkt. Binnen Het Kantoor is het echter ook van belang om te bekijken wat er gedaan kan worden om een dergelijke situatie te voorkomen. Vandaar dat in hoofdstuk 7 bekeken wordt wat dossiermedewerkers doen bij concrete problemen in het werk en hoe dossiermedewerkers bepaalde competenties aanleren.

Zestig procent van de dossiermedewerkers raadplegen een collega als ze ergens niet uitkomen, iets dat ook door de staf van Het Kantoor als belangrijk instrument gezien wordt in een 'lerende organisatie'. Vrouwen doen dit overigens vaker dan 
mannen. In tweede instantie werd geanalyseerd in welke mate dossiermedewerkers vonden dat ze bij bepaalde veranderingen genoeg hulp hebben gekregen. Het valt op dat een groot aantal medewerkers bij de veranderingen die de meeste problemen met zich heeft mee gebracht, de organisatorische veranderingen, vindt dat dit niet het geval is geweest. Wanneer gekeken wordt naar het soort hulp dat is aangeboden bij veranderingen, blijkt dat het bij veranderende regelgeving en automatisering vooral gaat om cursussen, terwijl organisatorische veranderingen vaak worden opgevangen door het raadplegen van collega's.

In het laatste deel van het hoofdstuk komen de leerbronnen van competenties aan de orde. Het blijkt dat de verschillende competenties van de medewerkers op heel verschillende manieren worden aangeleerd. Bij de ene competentie zijn het juist de cursussen die een belangrijke rol spelen, bij een andere geven veel medewerkers aan dat ze het altijd al goed konden, en bij weer andere competenties blijkt het contact met collega's of de baas essentieel bij het aanleren van een competentie.

Een en ander impliceert dat competentie-ontwikkeling en daarmee ook kwalificatieveroudering zeer complexe processen zijn, en dat eenvoudige theoretische kaders weliswaar in sommige situaties plausibel zijn, maar dat in andere gevallen een heel diepgaande analyse nodig is om die processen te begrijpen. In dit rapport is getracht juist dit te bereiken; de waarde ervan ligt dan ook in het scheppen van meer duidelijkheid rond kwalificatieveroudering, competentieproblemen en effectieve beleidsinstrumenten.

Een belangrijke conclusie van dit onderzoek is dat het voor een adequate competentie-ontwikkeling van cruciaal belang is dat het leerproces goed aansluit bij de problemen die medewerkers ondervinden. Het wordt daarom steeds belangrijker dat medewerkers zelf aangeven op welke wijze zij zich verder denken te kunnen ontplooien. Dit betekent dat er een grotere verantwoordelijkheid bij de medewerker komt te liggen om zelf initiatieven te nemen, maar ook dat de organisatie de competentie-ontwikkeling van medewerkers wellicht op een andere wijze zal moeten gaan ondersteunen. Een drietal hoofdfactoren staan een dergelijke aanpassing nog in de weg. Ten eerste dienen medewerkers en hun managers beide een helder beeld te hebben van de sterke en zwakke plekken van een dossiermedewerker. In de tweede plaats zouden de medewerkers duidelijker de verantwoordelijkheid voor de eigen ontwikkeling moeten voelen. Ten derde zou de organisatie een dergelijke attitude beter kunnen ondersteunen. Dit kan door cursussen, maar ook door bij de verdeling van werk meer oog te hebben voor de leermogelijkheden en zo te zorgen voor een leerrijke werkomgeving.

De analyses in dit rapport laten zien dat maatschappelijke en organisatorische veranderingen op velerlei wijze het functioneren van medewerkers kunnen beïnvloeden. Hoewel scholing een bijdrage kan leveren aan het verkleinen van deze problemen is het niet zo dat cursussen altijd een adequate oplossing vormen. Ook de wijze waarop het werk wordt ingericht en de houding van zowel medewerkers als bedrijf zijn bepalend voor een adequate competentie-ontwikkeling. Om ook op lan- 
delijk niveau een goed beeld te krijgen van de wijze waarop mensen middels onderwijs, scholing en werkervaring hun competenties weten aan te passen aan de veranderende behoeftes van de arbeidsmarkt, lijkt het van belang in de gegevensverzameling hieraan meer aandacht te geven. Op die wijze kunnen de bestaande inzichten met betrekking tot de relatie tussen kwalificatieveroudering en competentie-ontwikkeling door verder onderzoek verrijkt worden. Zo kan ook het beleid dat gericht is op het beperken van de risico's op verlies van werk beter vormgegeven worden. 
